\title{
FLEKSIBILITAS NILAI TUKAR DAN PENYESUAIAN TRANSAKSI BERJALAN DI INDONESIA: ANALISIS THRESHOLD VAR
}

\author{
Farhana Zahrotunnisa ${ }^{1}$, Iman Sugema ${ }^{2}$, Toni Bakhtiar ${ }^{2}$ \\ ${ }^{1}$ Mahasiswa Magister Program Studi Ilmu Ekonomi, FEM IPB \\ ${ }^{2}$ Staf Pengajar FEM IPB \\ Artikel diterima April 2015 \\ Artikel disetujui untuk dipublikasikan Desember 2015
}

\begin{abstract}
Estimation study about the relationship between exchange rate flexibility and current account adjustment has been through three stages, the first stage was analysis of correlation among exchange rates variability (proxied by REER and NEER) and exchange rate regimes classification. The second step was estimating the relationship that the former was mentioned with VAR as benchmark model. The third step was applying the nonlinear estimation with Threshold VAR. The results of analysis showed that exchange rate regime classification may not capture actual exchange rate variability and flexibility exchange rate can accelerate current account adjustment in Indonesia if the changes of Indonesia exchange rate less than 27.7059 (low regime) whereas in high regime exchange rate is persistent increasing so that the system between exchange rate and current account become unstable. Bank Indonesia as monetary authorities must keep the changes of exchange rate less than 27.7059, due to exchange rate can affect current account adjustment, so can anticipate if there is current account deficit in Indonesia economy.
\end{abstract}

Keywords : Exchange Rate Flexibility, Current Account Adjustment, Exchange Rate Regime Classification, Threshold VAR

\section{PENDAHULUAN}

\section{Latar Belakang}

Kinerja sektor eksternal sebuah perekonomian pada umumnya tercermin pada perkembangan neraca pembayaran yang selanjutnya akan berpengaruh pada nilai tukar. Komponen utama dalam neraca pembayaran adalah transaksi berjalan atau current account, transaksi modal atau capital and financial account dan perubahan cadangan devisa (Nugroho et al. 2012). Memburuknya kinerja transaksi modal sering dikaitkan dengan menurunnya aliran modal asing sedangkan memburuknya kinerja transaksi berjalan sering dikaitkan secara langsung dengan kinerja dan daya saing ekspor yang menurun atau peningkatan impor karena permintaan domestik yang meningkat.

Pada tahun 2008 terjadi krisis finansial global yang melanda Amerika Serikat (AS) kemudian merambat hampir keseluruh dunia termasuk Indonesia. Salah satu penyebab utama krisis keuangan global adalah ketidakseimbangan global (global imbalance) yang terjadi secara berkepanjangan. Ketidakseimbangan global merupakan suatu kondisi dimana suatu atau sekelompok negara mengalami defisit transaksi berjalan (current account deficit) sementara sekelompok negara lainnya mengalami surplus dalam skala yang sangat besar 
dan dalam waktu yang cukup lama (Ecthink 2009), sedangkan pada tahun 2010 terjadi krisis di kawasan Eropa yang dipicu oleh besarnya hutang pemerintah. Kedua krisis yang terjadi dalam waktu yang berdekatan berdampak pada menurunnya kinerja ekpor Indonesia dimana impor tetap tumbuh tinggi akibat permintaan domestik yang cukup kuat menyebabkan defisit transaksi berjalan sejak triwulan IV/2011.

Belum pulihnya krisis AS dan Eropa serta melemahnya perekonomian Jepang mengakibatkan pada tahun 2013 triwulan II Indonesia mengalami defisit transaksi berjalan terbesar sepanjang sejarah yaitu US\$ 9,8 miliar atau sekitar 4,4 \% dari GDP Indonesia. Menurut Milesi-Ferreti dan Razin (1996) suatu negara harus menjaga agar defisit transaksi berjalan tidak berlangsung lama, karena adanya defisit transaksi berjalan sebesar $5 \%$ dari GDP dapat memicu terjadinya currency crisis. Keberlanjutan defisit transaksi berjalan merefleksikan tingginya pengeluaran untuk konsumsi yang dibiayai oleh hutang jangka pendek atau cadangan devisa luar negeri. Sejarah mencatat bahwa ada beberapa negara yang mampu bertahan dalam kondisi defisit transaksi berjalan dalam beberapa tahun yaitu Australia, Irlandia, Israel, Malaysia, dan Korea Selatan. Kondisi tersebut berbanding terbalik dengan Negara Chili dan Mesiko yang harus mengalami krisis akibat tidak dapat bertahan dalam kondisi defisit transaksi berjalan.

Menurut Friedman Hyphotesis (Friedman 1953) adanya penyesuaian yang baik dalam menghadapi ketidakseimbangan pada transaksi berjalan memerlukan adanya fleksibilitas pada nilai tukar. Semakin besar fleksibilitas nilai tukar maka akan semakin besar kemampuan transaksi berjalan pada suatu negara dalam penyesuaian terhadap perubahan kondisi yang terjadi menuju sustainable level yang nantinya akan mengefisienkan penyesuaian nilai tukar nominal dibandingkan penyesuaian pada harga barang. Fleksibilitas nilai tukar sangat bergantung pada rezim nilai tukar yang dianut pada suatu negara. Sejarah perekonomian Indonesia mencatat bahwa Indonesia mengalami pergantian rezim nilai tukar bahkan sebelum Indonesia merdeka. Studi Adiningsih et al. (2008) menyatakan bahwa pada tahun 1997 rezim nilai tukar yang dianut oleh Indonesia berubah dari rezim nilai tukar tetap menjadi rezim nilai tukar mengambang. Hal ini sesuai dengan pengklasifikasian rezim nilai tukar secara de jure (deklarasi dari pemerintah/otoritas moneter) yang dilakukan oleh IMF. Menurut Duttagupta et al (2005) negara dengan fixed exchange rate (nilai tukar tetap) akan lebih rentan terhadap krisis keuangan dan krisis perbankan dibandingkan dengan negara yang menganut rezim flexible exchange rate (nilai tukar yang fleksibel). Hal ini dikarenakan rezim flexible exchange rate akan memiliki independensi kebijakan moneter yang lebih besar sehingga mampu memberikan perlindungan yang lebih baik terhadap guncangan yang terjadi pada perekonomian suatu negara.

Klasifikasi rezim nilai tukar yang ditetapkan secara de jure memiliki perbedaan/inkonsistensi dengan nilai tukar secara de facto (variasi nilai tukar yang terjadi/aktual) (Reinhart et al. 2004). Banyak negara yang menyatakan menganut rezim floating exchange rate (nilai tukar mengambang) namun tetap melakukan intervensi dalam implementasi kebijakan dalam mengatur nilai tukar. Hal ini yang melatarbelakangi terbentuknya 
pengklasifikasian nilai tukar secara de facto sebagai alternatif dari nilai tukar secara de jure. Alternatif pengklasifikasian nilai tukar ini bertujuan untuk menyempurnakan kelemahan yang ada pada sistem nilai tukar secara de jure. Pengklasifikasian rezim nilai tukar secara de facto telah dilakukan oleh beberapa peneliti seperti Levy-Yeyati dan Sturzenegger (LY-S), Reinhart, dan Rogoff (RR) serta Klein, dan Shambaugh (KS). Ketiga kelompok peneliti di atas mengklasifikasikan nilai tukar dengan cara yang berbeda-beda namun sama-sama menggunakan nilai tukar bilateral sebagai basis nilai tukar. Menurut studi yang dilakukan oleh Kim dan You (2013), pengklasifikasian nilai tukar dengan basis nilai tukar bilateral akan menimbulkan masalah karena tidak akan dapat menangkap variabilitas nilai tukar sebagai proksi nilai tukar aktual. Adanya perbedaan pada klasifikasi secara de jure dan de facto serta adanya permasalahan pada klasifikasi de facto akan menyulitkan dalam pemilihan serta penggunaan klasifikasi yang tepat dalam melihat hubungan antar fleksibilitas nilai tukar dengan penyesuaian neraca transaksi berjalan.

Permasalahan yang telah disebutkan di atas dapat diatasi dengan melakukan pengujian awal untuk mengidentifikasi klasifikasi nilai tukar mana yang dapat merefleksikan nilai tukar aktual Indonesia. Pengujian awal ini dilakukan dengan cara menguji korelasi klasifikasi nilai tukar yang ada dengan perhitungan variabilitas nilai tukar yang diproksikan dengan rata-rata triwulanan dari presentase perubahan bulanan dan standar deviasi dari nilai tukar efektif ${ }^{1}$. Hubungan fleksibilitas nilai tukar dengan penyesuaian neraca

\footnotetext{
${ }^{1}$ Standar deviasi umum digunakan dalam mengukur fleksibilitas nilai tukar seperti pada Rose (2003), Devereux dan Lane (2003)
}

transaksi berjalan dilakukan analisis secara asimetris mengingat adanya perbedaan rezim nilai tukar yang terjadi di Indonesia yang diduga dapat memberikan pengaruh yang berbeda pada penyesuaian neraca transaksi berjalan.

Banyak penelitian yang mengkaji hubungan antara fleksibilitas nilai tukar dengan transaksi berjalan dengan hasil yang berbeda. Herrmann (2009), melakukan penelitian di negara Central and Eastren Europe (CEE) dari tahun 1994 sampai dengan tahun 2007, diperoleh hasil bahwa bahwa terdapat hubungan yang signifikan antara rezim nilai tukar dengan penyesuaian neraca transaksi berjalan. Adanya rezim nilai tukar dengan fleksibilitas yang tinggi akan membuat ekspektasi dari para pembuat kebijakan meningkat mengenai proses penyesuaian transaksi berjalan. Namun penelitian yang dilakukan Hermann tidak sejalan dengan penelitan Chinn and Wei (2013) yang melakukan penelitian terhadap 170 negara dari tahun 1971 sampai dengan tahun 2005. Dari hasil penelitian tersebut disimpulkan bahwa tidak ditemukannya hubungan antara rezim nilai tukar yang fleksibel dengan penyesuaian dari transaksi berjalan. Dalam penelitian mengenai hubungan fleksibilitas nilai tukar dengan penyesuaian neraca transaksi berjalan banyak dilakukan analisis secara asimetris dikarenakan adanya perbedaan rezim nilai tukar dalam kurun waktu yang berbeda yang diduga dapat memberikan pengaruh yang berbeda pada penyesuaian neraca transaksi berjalan.

Tujuan penelitian ini adalah mengetahui klasifikasi nilai tukar mana yang dapat merefleksikan nilai tukar aktual Indonesia dan pembuktian apakah Friedman Hyphothesis berlaku di Indonesia atau tidak. 


\section{TINJAUAN PUSTAKA}

Penelitian atau literatur mengenai penyesuaian transaksi berjalan dengan keterkaitannya dengan kondisi perekonomian terbuka dan pendekatan intertemporal sudah dimulai sejak tahun 1982, namun menurut Hermann (2009) penelitian yang melihat hubungan antara rezim nilai tukar dan penyesuaian transaksi berjalan pertama kali dilakukan oleh Chinn dan Wei (2008).

Chinn dan Wei (2008) melakukan penelitian pada 170 negara yang terdiri dari negara maju dan berkembang (menurut klasifikasi IMF) selama tahun1971-2005. Penelitian yang dilakukan menggunakan dua rezim tukar de facto yaitu klasifikasi nilai tukar Levy-Yeyati, dan Sturzenegger serta Reinhart, dan Rogoff. Penggunaan dua klasifikasi bertujuan untuk melakukan perbandingan karena menurut pendapat Frankel (2007) yang menyebutkan bahwa dua klasifikasi tersebut hanya memiliki korelasi 0,4 . Hal ini menandakan adanya konsep yang berbeda jauh dalam melakukan pengklasifikasian rezim nilai tukar. Hasil penelitian memperlihatkan bahwa dengan menggunakan rezim nilai tukar Levy-Yeyati dan Sturznegger derajat persistensi dari transaksi berjalan sebesar 0,63 di bawah rezim flexible exchange rate, kemudian derajat persisten akan mengalami kenaikan hingga 0,76 dan 0,79 di bawah rezim fixed exchange rate. Ketika klasifikasi rezim nilai tukar Reinhart dan Rogoff (2004) digunakan hasilnya tidak jauh berbeda dengan penggunaan rezim nilai tukar Levy-Yeyati, dan Sturznegger, derajat persistensi di bawah flexible exchange rate memiliki nilai 0,663 sedangkan di bawah rezim flexible exchange rate memiliki nilai derajat persisten sebesar 0,719. Dari kedua hasil tersebut dapat disimpulkan bahwa tidak diperoleh hasil yang robust dalam mengestimasi hubungan fleksibilitas nilai tukar dengan penyesuaian transaksi berjalan.

Hermann (2009) dengan mengadopsi cara kerja Chinn dan Wei (2008) dalam mengestimasi hubungan antara nilai tukar dan transaksi berjalan memperoleh hasil yang berbeda, di mana fleksibilitas nilai tukar ternyata mempengaruhi penyesuaian pada transaksi berjalan. Perbedaan yang terjadi menurut Hermann (2009) disebabkan karena pertama Chinn dan Wei (2008) menggunakan rezim nilai tukar Levy-Yeyati dan Sturznegger yang diubah menjadi dummy sebagai proksi dari fleksibilitas nilai tukar sedangkan nilai tukar Reinhart dan Rogoff (2004) tidak diubah menjadi variabel dummy. Adanya pengubahan pada rezim nilai tukar tersebut diindikasi tidak dapat menangkap nilai tukar aktual. Kedua, data yang digunakan oleh Chinn dan Wei (2008) memiliki heterogenitas yang besar dan standar error nya memiliki perilaku yang berbeda di setiap sub-sampel. Adanya permasalahan di atas dapat diperbaiki oleh Hermann (2009) dengan cara menggunakan z-scores sebagai proksi dalam mengukur volatilitas nilai tukar, kemudian sampel yang digunakan homogen. Estimasi dilakukan di emerging market dikarenakan adanya permasalah ini lebih terfokus pada negara berkembang.

Decressin dan Stavrev (2009) mengestimasi hubungan antara keseimbangan transaksi berjalan dengan nilai tukar mata uang di European Economic and Monetary Union (EMU) pada masa sebelum dan sesudah monetary union terbentuk pada tahun 1999. Penelitian ini dilatarbelakangi adanya kekhawatiran mengenai tidak adanya mata uang nasional pada negara di kawasan Eropa, sehingga ketika 
adanya guncangan tertentu pada suatu negara dikawasan tersebut akan mengakibatkan besar dan lamanya ketidakseimbangan transaksi berjalan antara negara anggota, serta akan merusak independensi dari kebijakan moneter. Pada penelitian ini nilai tukar diproksikan oleh real effective exchange rate (nilai tukar riil efektif), diperoleh hasil bahwa pada negara di EMU pada kedua kurun waktu yang berbeda tidak terdapat hubungan timbal balik antara perbedaan transaksi berjalan pada negara EMU dengan nilai tukar. Pada penelitian ini diestimasi juga mengenai faktor-faktor apa yang menyebabkan perbedaan pada transaksi berjalan di negara EMU, yaitu pendapatan dan keadaan demografi negara masingmasing.

Kim dan You (2013) menganalisis hubungan nilai tukar dengan penyesuaian transaksi berjalan dengan menggunakan Threshold VAR. Dalam estimasinya Kim dan You (2013) menggunakan nilai tukar de facto dan de jure serta standar deviasi dari nilai tukar efektif sebagai proksi untuk fleksibilitas nilai tukar. Penelitian dilakukan dengan kurun waktu 19802010 di 90 negara. Adanya nilai threshold sebesar 7,41 kemudian akan membagi keseluruhan sampel ke dalam dua bagian berdasarkan variabilitas nilai tukar rendah dan tinggi. Di bawah variabilitas nilai tukar yang rendah koefisien lag satu dan dua yaitu 0,82 dan -0,15, sedangkan di bawah variabilitas nilai tukar yang tinggi diperoleh koefisien lag satu dan dua sebesar 0,64 dan -0,1. Kedua estimasi tersebut signifikan di level 1 persen. Hasil penelitian ini mengindikasikan bahwa keseimbangan transaksi berjalan kurang persisten di bawah regim nilai tukar dengan variabilitas yang tinggi. Dengan kata lain, keseimbangan transaksi berjalan akan melakukan penyesuaian lebih cepat pada rezim nilai tukar yang lebih fleksibel. Hal ini sesuai dengan Friedman Hyphotesis.

\section{METODE PENELITIAN}

\section{Jenis dan Sumber Data}

Penelitian mengenai pembuktian fleksibilitas nilai tukar terhadap penyesuaian neraca transaksi berjalan di Negara Indonesia ini akan di mulai dengan melihat hubungan antara klasifikasi rezim nilai tukar yang ada dengan variabilitas nilai tukar (proksi nilai tukar aktual). Dilanjutkan dengan melakukan estimasi VAR dan Threshold VAR untuk melihat hubungan bilateral antara fleksibilitas nilai tukar dengan penyesuaian transaksi berjalan. Jenis data yang digunakan dalam penelitian ini adalah data sekunder agregat untuk Negara Indonesia dalam bentuk deret waktu triwulan (quarterly time series) periode 1993Q2 sampai dengan 2013Q3.

Data diperoleh melalui SEKI BI (Statistik Ekonomi dan Keuangan Indonesia), Badan Pusat Statstik, IFS (International Financial Statistic) serta web terkait. Data-data yang digunakan dibagi menjadi dua kelompok yaitu data yang digunakan untuk melihat hubungan klasifikasi rezim nilai tukar dengan variabilitas nilai tukar yaitu klasifikasi rezim nilai tukar IMF, LYS, RR dan KS, kemudian proksi variabilitas nilai tukar yaitu $\mid \% \Delta$ neer $\mid$, $\% \Delta$ nber | dimana rata-rata triwulan nilai absolut dari perubahan presentase tahunan pada nilai tukar nominal efektif dan nilai tukar nominal bilateral, serta SD $(\% \Delta$ neer $)$, SD $(\% \Delta$ nber $)$ dimana rata-rata triwulan standar deviasi dari perubahan presentase bulanan pada nilai tukar nominal efektif dan nilai tukar bilateral

Sedangkan data yang digunakan untuk mengestimasi hubungan 
fleksibilitas nilai tukar dan penyesuaian neraca transaksi berjalan yaitu Riil Effective Exchange Rate (LOGREER) sebagai proksi variabilitas nilai tukar ${ }^{2}$ dan Rasio transaksi berjalan dengan GDP (CurrentAC) ditambah dengan tiga variable kontrol yaitu rasio ekspor dan impor dengan GDP (Trade Openess) (Openc), rasio outstanding credit dengan GDP (Financial Development) (Fin_Dvp), dan rasio pendapatan Indonesia dengan Amerika Serikat (Relative Income) (Logr_inc) dimana variabel threshold untuk estimasi ini adalah klasifikasi rezim nilai tukar terpilih dan nilai absolut dari persentase perubahan triwulanan di REER ${ }^{2}$.

\section{Metode Analisis Data}

\section{Analisis Deskriptif}

Analisis deskriptif digunakan untuk menggambarkan keadaan secara umum dan perkembangan inklusi keuangan serta ketimpangan pendapatan yang terjadi di berbagai provinsi di Indonesia.

\section{Analisis Threshold Vector Autoregression (TVAR)}

Metode Threshold Vector Autoregression (TVAR) merupakan model dari Vector Autoregression (VAR) yang secara umum bertujuan untuk menangkap adanya ketaklinearan pada sistem karena adanya perpindahan periodik secara asimetri, perubahan rezim dan lain lain. Secara umum, model yang digunakan dalam analisis threshold VAR adalah sebagai berikut:

$Y_{t}=D^{1}+A^{1} Y_{t}+B^{1}(L) Y_{t-1}+$ $\left(D^{2}+A^{2} Y_{t}+B^{2}(L) Y_{t-1}\right) I_{t}\left[c_{t-d}>\right.$ $\gamma]+e_{t}$

\footnotetext{
${ }^{2}$ REER dan NEER memiliki pergerakan searah dan korelasi yang tinggi pada kondisi negara dengan tingkat inflasi yang rendah (Musa, 1986)
}

di mana $Y_{t}$ adalah vektor variabel endogen, $I_{t}\left[c_{t-d}>\gamma\right]$ variabel yang memiliki nilai 1 ketika lag variabel threshold $c_{t}$ lebih rendah dibandingkan dengan critical value threshold $\gamma$ sedangkan 0 lainnya. Model mengidentifikasikan dua rezim yang terpisah berdasarkan $c_{t-d}$ di mana $d$ merupakan time lag, relatif terhadap $\gamma$ yang secara endogen ditentukan pada sistem.

Terlihat pada persamaan 1.1 model linear VAR , ketika nilai $I_{t}\left[c_{t-d}>\gamma\right]$ bernilai 0 maka hasil estimasi akan diperoleh $D^{1}, A^{1}$ dan $B^{1}(L)$ sedangkan jika $I_{t}\left[c_{t-d}>\gamma\right]$ bernilai 1 maka hasil estimasi akan diperoleh $\quad D^{1}+D^{2}, \quad A^{1}+A^{2}$ dan $B^{1}(L)+B^{2}(L)$. Dengan demikian adanya asimetri pada model dapat ditangkap oleh variabel threshold dengan vector constant term $D$, koefisien matriks $A$, dan $B(L)$ yang berbeda pada setiap rezim.

Variabel threshold $c_{t}$ digunakan untuk pembeda pada rezim yang dimodelkan sebagai variabel di vektor $Y_{t}$. Hal ini mengakibatkan adanya pergantiaan rezim yang di tentukan secara endogen pada sistem itu sendiri. Permodelan pada VAR mempertimbangkan semua variabel pada sistem sebagai endogenous shocks pada setiap variabel di $Y_{t}$, sehingga adanya dampak pada variabel $c_{t}$ akan mengakibatkan pergeseran pada rezim yang berbeda.

Adanya keberadaan variabel threshold pada model Threshold VAR harus di uji validitasnya terlebih dahulu di mana $D^{2}=A^{2}=B^{2}(L)=0$. Perlu diperhatikan jika critical value threshold $\gamma$ hanya berlaku pada model Threshold VAR dan tidak berlaku secara umum. Setelah model terbentuk dan koefisien di estimasi, maka model akan dievaluasi dengan nonlinear impulse respons analysis. 


\section{Perumusan Model Penelitian}

Spesifikasi model dalam penelitian ini mengacu pada model yang digunakan pada Kim dan You (2013) dengan variabel utama yaitu proksi dari variabilitas nilai tukar pada estimasi menggunakan Threshold VAR yaitu Riil Effective Exchange Rate (REER) dan Rasio transaksi berjalan dengan GDP (CA) ditambah dengan tiga variable kontrol yaitu rasio ekspor dan impor dengan GDP, rasio outstanding credit dengan GDP, dan rasio pendapatan Indonesia dengan Amerika Serikat. Pada uji korelasi dengan klasifikasi rezim nilai tukar, proksi variabilitas nilai tukar menggunakan Nominal Effective Exchange Rate (NEER). Hal ini dilakukan karena klasifikasian rezim nilai tukar secara de facto dan de jure menggunakan nilai tukar nominal sebagai dasar dari pengklasifikasian yang telah dilakukan. Menurut Musa (1986), dalam kondisi suatu negara dengan nilai inflasi yang rendah, maka korelasi REER dan NEER akan tinggi dan memiliki pergerakan yang searah.
Berikut adalah model Threshold VAR yang digunakan dalam penelitian ini:

Di mana :

$$
\begin{aligned}
Y_{t}=B^{1}(L) Y_{t} & +\beta^{1} X_{t} \\
& +\left(B^{2}(L) Y_{t}\right. \\
& \left.+\beta^{2} X_{t}\right) I_{t}\left[S_{t-d}\right. \\
& >\gamma]+U_{t}
\end{aligned}
$$

\begin{tabular}{|c|c|}
\hline$Y_{t}$ & $\begin{array}{l}=\text { Vektor variabel endogen (CA } \\
\text { dan REER) }\end{array}$ \\
\hline$X_{t}$ & $\begin{aligned} \text { = Vektor variabel eksogen } \\
\text { termasuk variabel kontrol } \\
\text { (OPENC, FIN_DVP, R_INC) }\end{aligned}$ \\
\hline$\beta^{1}$ & $=$ Koefisien variabel eksogen \\
\hline$S$ & $=$ Variabel threshold \\
\hline$d$ & $=$ Time lag \\
\hline & $\begin{array}{l}=\text { Fungsi indikator yang } \\
\text { memiliki nilai } 1 \text { ketika lag } \\
\text { variable threshold } s_{t} \text { lebih } \\
\text { rendah dibandingkan dengan } \\
\text { critical value threshold } \gamma \\
\text { sedangkan } 0 \text { lainnya }\end{array}$ \\
\hline & $3^{2}(L)=L a g$ matriks polinomial \\
\hline
\end{tabular}

\begin{tabular}{|c|c|c|}
\hline No. & Notasi & Variabel \\
\hline & \multicolumn{2}{|l|}{ Kategori 1} \\
\hline $1 .$. & $C A$ & Keseimbangan Transaksi Berjalan (Current Account Balance) \\
\hline 2. & OPENC & Keterbukaan Sektor Perdagangan (Trade Openness) \\
\hline 3. & $F I N \_D V P$ & Pembangunan Sektor Keuangan (Financial Development) \\
\hline 4. & $R \_I N C$ & Pendapatan Relatif (Relative Income) \\
\hline 5. & REER & Nilai tukar riil efektif \\
\hline 6. & $\gamma$ & Nilai Threshold \\
\hline 7. & $U$ & Error term \\
\hline 8. & $t$ & Periode \\
\hline \multicolumn{3}{|c|}{ Kategori 2} \\
\hline 1. & NEER & Nilai tukar nominal efektif \\
\hline 2. & REER & Nilai tukar riil efektif \\
\hline 3. & $S D($ persen $\triangle N E E R)$ & Standar deviasi dari persentase bulanan NEER \\
\hline 4. & $S D($ persen $\triangle N B E R)$ & Standar deviasi dari persentase bulanan NBER \\
\hline 5. & $I M F$ & Klasifikasi rezim IMF \\
\hline 6. & $R-R$ & Klasifikasi rezim $\mathrm{R}-\mathrm{R}$ \\
\hline 7. & $L Y-S$ & Klasifikasi rezim LY-S \\
\hline 8. & $K-S$ & Klasifikasi rezim K-S \\
\hline
\end{tabular}

Tabel 1 Variabel-variabel yang digunakan dalam penelitian 
Tabel 1 memuat mengenai variabel-variabel yang digunakan secara keseluruhan di dalam penelitian ini. Variabel tersebut akan dikelompokan ke dalam dua kategori yaitu kategori pertama variabel yang masuk dalam model dan kategori kedua yaitu variabel yang masuk dalam uji korelasi yang akan dilakukan sebelum estimasi Threshold VAR.

\section{PEMBAHASAN}

\section{Kondisi Neraca Transaksi Berjalan di Indonesia}

Neraca transaksi berjalan sebagai indikator dalam melihat kondisi ekternal Indonesia dalam kurun waktu 1993Q1 hingga 2013Q3 mengalami kondisi defisit dan surplus yang silih berganti. Dilihat dari presentase defisit yang terbesar dalam kurun waktu 1993 hingga 2013 terjadi pada tahun 1995Q2 yaitu sebesar -4.8 persen dari GDP Indonesia. Hal ini disebabkan oleh menurunnya volume ekspor minyak bumi sebesar 4 persen dan LNG (gas alam cair sebesar 0.5 persen akibat meningkatnya konsumsi dalam negeri, menurunnya harga dan volume ekspor beberapa komoditas pertanian serta belum pulihnya ekspor beberapa komoditas manufaktur andalan serta adanya kenaikan ongkos angkut dan asuransi impor nonmigas, pembayaran bunga pinjaman luar negeri yang menyebabkan defisit jasa semakin besar (Bappenas,1996). Dalam kurun waktu yang sama presentase surplus terbesar pada neraca transaksi berjalan terjadi pada tahun 1998Q2 sebesar 11.25 persen. Pada triwulan kedua, beberapa indikator ekonomi makro mulai menunjukan perkembangan ke arah perbaikan. Namun krisis ekonomi yang terus berlanjut telah menyebabkan perekonomian semakin parah. Hal ini ditandai dengan tingkat penggangguran yang meningkat tajam dan pendapat per kapita yang menurun.

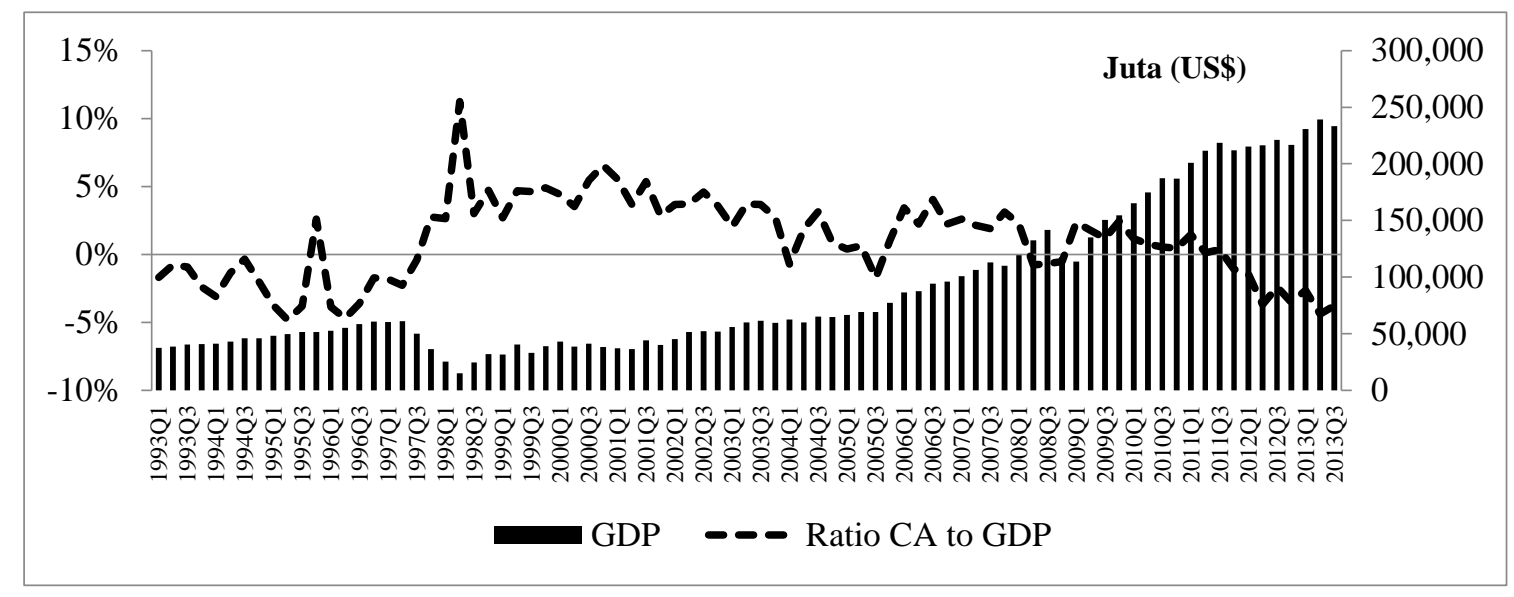

Gambar 1 Share neraca transaksi berjalan terhadap GDP di Indonesia

Sektor eksternal juga mengalami penurunan, meskipun memiliki nilai yang surplus, kinerja ekspor dan impor memburuk. Kondisi ini semakin diperparah dengan disertai meningkatnya tekanan inflasi dan gejolak nilai tukar yang tajam (LPI, 1999). Pasca krisis global tahun 2008, perekonomian Indonesia mampu tumbuh tinggi disertai stabilitas yang terjaga. Hal ini disebabkan oleh dua tren global yaitu pertama kondisi term of 
trade yang membaik didorong kenaikan harga ekspor komoditas primer (permintaan dari negara emerging market seperti China dan India meningkat). Kedua, adanya kebijakan stimulus moneter di negara maju pasca krisis global yang menyebabkan likuiditas global mengalir ke perekonomian emerging market termasuk Indonesia yang menyebabkan suku bunga dapat dijaga dengan nilai yang rendah dan stabil. Namun kondisi tersebut hanya dapat berlangsung sekitar empat tahun. Pada tahun 2013, didorong bergesernya kedua tren global yang telah disebutkan di atas; melambatnya pertumbuhan ekonomi negara emerging market, menurunnya terms of trade Indonesia, kinerja ekspor turun serta berkurangnya stimulus moneter dari negara maju menyebabkan ketidakseimbangan pada neraca pembayaran Indonesia yang ditandai dengan melebarnya defisit transaksi berjalan (Gambar 1). Defisit transaksi berjalan terbesar pada tahun 2013 terjadi pada triwulan kedua yaitu sebesar -4.38 persen, disebakan karena rupiah terdepresiasi akibat pengurangan stimulus The Fed, ekspektasi inflasi yang meningkat pasca penerapan pembatasan impor komoditas pangan dan adanya penguran subsidi BBM yang dilakukan oleh otoritas fiskal Indonesia.

\section{Kondisi Nilai Tukar di Indonesia}

Analisis dalam suatu penelitian yang melibatkan nilai tukar dalam variabel yang diestimasi mensyaratkan sensitivitas pada indeks nilai tukar yang digunakan. Menurut Opoku-Afari (2011), terdapat beberapa alternatif dalam melakukan perhitungan pada nilai tukar dan pemilihan indeks nilai tukar yang bergantung pada objek penelitian. Nilai tukar dibagi menjadi dua yaitu nilai tukar nominal dan nilai tukar riil, di mana nilai tukar riil memperhitungkan adanya perubahan harga pada suatu perekonomian.

Secara teori, terdapat dua definisi nilai tukar riil:

1. Dari sisi eksternal, didefinisikan sebagai nilai tukar nominal yang disesuaikan dengan perbedaan tingkat harga di beberapa negara atau rasio dari tingkat harga luar negeri secara agregat terhadap agregat tingkat harga dalam negeri yang diukur berdasarkan nilai tukar secara umum (lebih dari satu negara).

2. Dari sisi internal, didefinisikan sebagai rasio dari harga domestik barang tradable terhadap barang non-tradable di dalam satu negara.

Penelitian ini, fokus menggunakan nilai tukar dengan definisi secara eksternal yang umum dikenal dengan nilai tukar riil efektif real effective exchange rate. Penggunaan nilai tukar ini didasarkan pada tujuan penelitian untuk melihat adanya hubungan penyesuaian nilai tukar terhadap neraca transaksi berjalan, di mana neraca transaksi berjalan terdiri dari kegiatan ekspor impor yang melibatkan interaksi banyak negara, sehingga pemilihan nilai tukar riil efektif dengan komposisi rasio bobot tingkat harga merupakan pilihan yang tepat dalam mendukung analisis pada penelitian ini.

Gambar 2 berikut merupakan gambar dari REER dan NEER Indonesia. Seperti yang dikemukakan oleh Mussa (1986) di lingkungan dengan inflasi yang rendah, nilai tukar nominal dan riil memiliki pergerakan yang serupa. Inflasi yang rendah memiliki kisaran nilai antara $2-3$ persen. Inflasi Indonesia memiliki ratarata dari $1-5$ persen. Dari gambar terlihat bahwa Indonesia memiliki 
tingkat inflasi yang tinggi pada tahun 1997 pada saat terjadinya krisis, tahun 2005 pada saat harga BBM mengalami kenaikan, dan pada tahun 2013 di mana Indonesia mengalami dampak pemulihan perekonomian dari negara maju. Jika dilihat dari pergerakan tren pada REER dan NEER Indonesia mengalami tren yang sama dari tahun 1993Q2 hingga tahun 2005Q2 di mana nilai REER selalu lebih tinggi dibandingkan dengan nilai NEER, sedangkan setelah tahun 2005Q2 NEER memiliki tren yang terus meningkat sedangkan REER memiliki tren yang menurun, meskipun tetap dengan pergerakan yang serupa. Meningkatnya indeks REER dan NEER menandakan bahwa nilai tukar mengalami apresiasi dan sebaliknya.

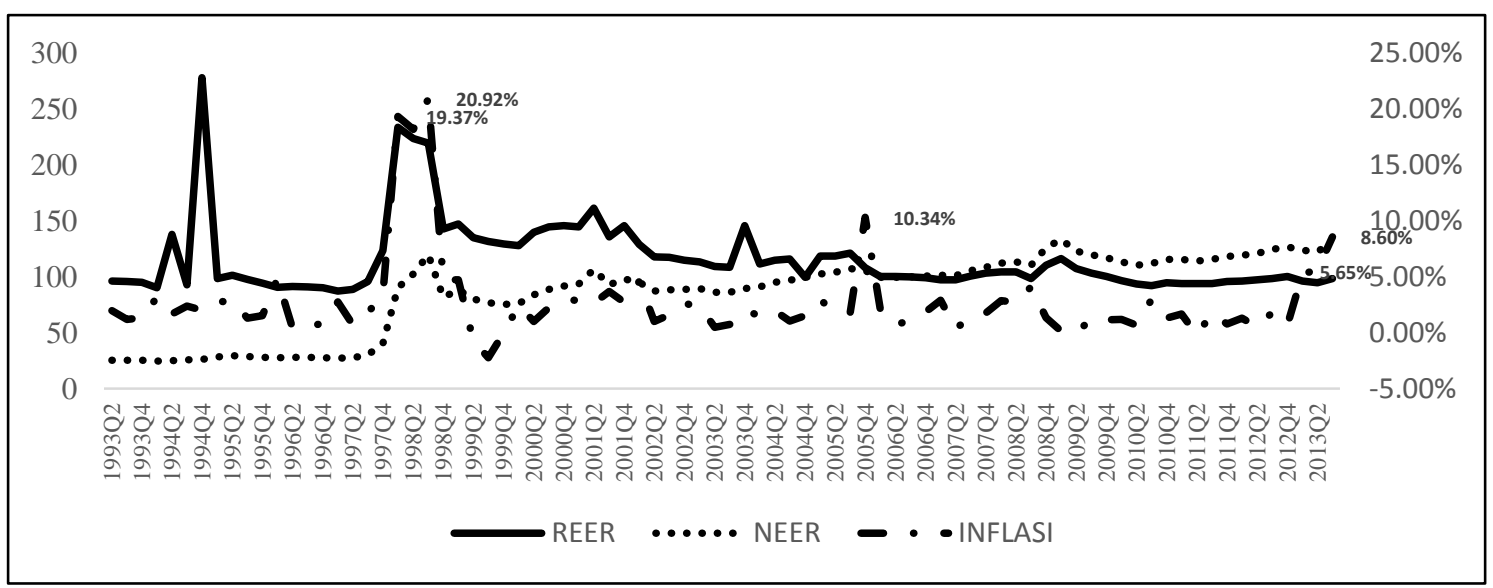

Gambar 2 REER, NEER, dan Inflasi

\section{Statistik Deskriptif}

Tabel 2 menunjukan statistik deskriptif semua variabel yang digunakan dalam penelitian. Selama kurun waktu 1993Q2 hingga 2013Q2, rata-rata presentase neraca transaksi berjalan dengan GDP di Indonesia adalah 1.02 persen dengan nilai minimum -4.81 persen dan nilai maksimum 11.25 persen. Nilai minimum dan maksimum ini terjadi pada 1995Q2 dan 1998Q2. Sementara rata-rata nilai REER adalah 115.84 dengan nilai minimum 87.55 dan maksimum 278.21, nilai ini terjadi pada 1997Q1 (Krisis ekonomi) dan 1994Q4. Untuk nilai NEER memiliki rata-rata sebesar 86.01 dengan nilai minimum 34.65 yang terjadi pada 1994Q1 dan nilai maksimum sebesar 133.60 yang terjadi pada 2009Q1. Pada kurun waktu 1994Q1 terjadi krisis Eropa dan pada kurun waktu 2009Q1 sedang berlangsung recovery perekonomian Amerika Serikat. Sedangkan rata-rata OPENC, R_INC dan FIN_DVP secara berturut-turut yaitu 0.58, 0.01, dan 1.23. Sedangkan untuk empat klasifikasi regim nilai tukar memiliki nilai diskret yang berkisar antara 0 hingga 5 .

Tabel 2 Statistik Deskriptif Variabel Penelitian

\begin{tabular}{cccccc}
\hline Variabel & T & $\begin{array}{c}\text { Rata- } \\
\text { Rata }\end{array}$ & $\begin{array}{c}\text { Standar } \\
\text { Deviasi }\end{array}$ & $\begin{array}{c}\text { Nilai } \\
\text { Min }\end{array}$ & $\begin{array}{c}\text { Nilai } \\
\text { Maks }\end{array}$ \\
\hline CA & 82 & 1.02 & 3.092 & -4.81 & 11.25 \\
REER & 82 & 115.84 & 33.58 & 87.55 & 278.21 \\
NEER & 82 & 86.01 & 34.65 & 24.72 & 133.60 \\
R_INC & 82 & 0.01 & 0.00 & 0.01 & 0.02 \\
OPENC & 82 & 0.58 & 0.13 & 0.35 & 1.11 \\
FIN_DVP & 82 & 1.23 & 0.51 & 0.66 & 2.81 \\
IMF_CLASS & 82 & 3.20 & 0.40 & 3 & 4 \\
KS_CLASS & 82 & 0.09 & 0.28 & 0 & 1 \\
LYS_CLASS & 82 & 4.26 & 1.00 & 2 & 5 \\
RR_CLASS & 82 & 2.87 & 0.64 & 2 & 5 \\
\hline Ket_:T adalah &
\end{tabular}

Ket : T adalah jumlah observasi 


\section{Klasifikasi Rezim Nilai Tukar dan Fleksibilitas Nilai Tukar}

Langkah awal yang dilakukan sebelum mengestimasi fleksibilitas nilai tukar terhadap penyesuaian transaksi berjalan yaitu melakukan uji korelasi antara klasifikasi rezim nilai tukar dengan variabilitas nilai tukar. Hal ini bertujuan untuk mengecek apakah klasifikasi rezim nilai tukar yang ada dapat merepresentasikan nilai tukar aktual terlepas dari kekurangan dari rezim nilai tukar yang telah dijelaskan sebelumnya.

Tabel 3 Hasil Uji Korelasi Semua

Proksi Variabilitas dan

Klasifikasi Rezim Nilai Tukar

\begin{tabular}{lllllllll}
\hline & $(1)$ & $(2)$ & $(3)$ & $(4)$ & $(5)$ & $(6)$ & $(7)$ & $(8)$ \\
\hline$(1)$ & 1 & & & & & & & \\
$(2)$ & 0.99 & 1 & & & & & & \\
$(3)$ & 0.84 & 0.83 & 1 & & & & & \\
$(4)$ & 0.84 & 0.83 & 0.99 & 1 & & & & \\
$(5)$ & 0.7 & 0.73 & 0.72 & 0.74 & 1 & & & \\
$(6)$ & -0.1 & -0.10 & -0.19 & -0.16 & 0.4 & 1 & & \\
$(7)$ & -0.03 & -0.06 & -0.07 & -0.08 & 0.3 & 0.3 & 1 & \\
$(8)$ & 0.47 & 0.48 & 0.64 & 0.63 & 8 & 0.3 & 0.1 & 1 \\
\hline
\end{tabular}

$\begin{array}{ll}\text { Ket : (1) }|\Delta \% \mathrm{NEER}| & \text { (6) LY_CLASS } \\ \text { (2) }|\Delta \% \mathrm{NBER}| & \text { (7) KS_CLASS } \\ \text { (3) } \mathrm{SD}(\Delta \% \mathrm{NEER}) & \text { (8) IMF_CLASS } \\ \text { (4) } \mathrm{SD}(\Delta \% \mathrm{NBER}) & \\ \text { (5) RR_CLASS } & \end{array}$

Pada hasil uji korelasi terlihat empat hal yang dapat diperhatikan yaitu pertama dari empat variabel yang dihitung sebagai proksi variabilitas nilai tukar yang mencakup nilai tukar bilateral dan multilateral memiliki nilai korelasi yang tinggi dengan kisaran 0.8 - 0.9. Hal ini mengindikasikan jika penyesuaian rupiah didominasi atau terpatok oleh mata uang negara yang berpengaruh (Amerika Serikat).
Kedua, hasil uji korelasi dari keempat klasifikasi rezim nilai tukar memiliki nilai dengan kisaran $-0.1-$ 0.4. Nilai korelasi yang negatif terdapat pada korelasi antara klasifikasi KS dengan klasifikasi rezim nilai tukar yang lain serta korelasi klasifikasi LYS dengan klasifikasi IMF. Adanya nilai korelasi yang negatif dan nilai korelasi yang positif tetapi memiliki besaran yang tidak terlalu besar $(0.28-0.41)$ (korelasi yang lemah), mengindikasikan bahwa terdapat kesulitan dalam pada empat klasifikasi rezim nilai tukar dalam merefleksikan nilai tukar aktual pada Indonesia.

Ketiga, hasil uji korelasi antara keempat variabel proksi variabilitas nilai tukar dan keempat klasifikasi rezim nilai tukar memiliki nilai korelasi antara $(-0.03-0.74)$. Hal ini dapat menjelaskan beberapa fakta bahwa pertama pengukuran klasifikasi rezim nilai tukar menggunakan data diskrete sedangkan proksi variabel nilai tukar menggunakan data kontinyu. Kedua yaitu klasifikasi rezim nilai tukar IMF, LYS, dan KS tidak dapat merefleksikan nilai tukar aktual Indonesia ((korelasi lemah). Sedangkan klasifikasi RR dapat lebih baik merefleksikan nilai tukar karena memiliki nilai korelasi yang paling tinggi 0,74 dibandingkan yang lain.

Hal ini disebabkan karena klasifikasi RR dilakukan berdasarkan suku bunga pasar dibandingkan dengan suku bunga official yang sejalan dengan pengukuran empat variabel proksi variabilitas nilai tukar. Fakta yang ketiga yaitu dengan nilai korelasi yang beragam (korelasi positif dan negatif), mengindikasikan bahwa beberapa klasifikasi rezim nilai tukar satu sama lain kurang dapat diperbandingkan karena memiliki dasar pengukuran yang berbeda contohnya yaitu klasifikasi LYS di mana pengukuran pada 
klasifikasi ini berdasarkan cadangan devisa sedangkan klasifikasi yang lain tidak. Dari hasil keseluruhan uji korelasi yang telah dilakukan maka ditetapkan klasifikasi rezim nilai tukar RR sebagai variabel threshold dalam melakukan estimasi lanjutan mengenai hubungan fleksibilitas nilai tukar terhadap penyesuaian neraca transaksi berjalan.

\section{Data Generating Process}

Sebelum menggunakan model VAR untuk mengestimasi hubungan fleksibilitas nilai tukar dengan penyesuaian neraca transaksi berjalan, perlu dilakukan Data Generating Procces (DGP). DGP terdiri dari pengujian stasioneritas, penetapan lag optimal, uji stabilitas dan uji kointegrasi.

\section{Pengujian Stasioneritas}

Menurut Gujarati (2004) stasioneritas merupakan asumsi dasar dalam estimasi penggunaan data time series. Sebuah data dikatakan stasioner jika nilai rata-rata dan varian konstan sepanjang waktu.

Tabel 4 Hasil Uji Stasioneritas Variabel Penelitian di Level

\begin{tabular}{|c|c|c|c|c|}
\hline & None & Constant & $\begin{array}{l}\text { Constant } \\
\& \text { Trend }\end{array}$ & Trend $^{2}$ \\
\hline REER & -0.19 & $\begin{array}{c}-4.64 * * \\
*\end{array}$ & $\begin{array}{c}-5.01 * * \\
*\end{array}$ & $\begin{array}{c}-5.32 * \\
* *\end{array}$ \\
\hline $\mathrm{CA}$ & $\begin{array}{c}-2.03 \\
* *\end{array}$ & -2.09 & -2.07 & $-3.7^{*}$ \\
\hline $\begin{array}{l}\text { FIN_D } \\
\text { VP }\end{array}$ & -0.78 & -1.38 & -1.1403 & -2.40 \\
\hline $\begin{array}{l}\text { OPEN } \\
\text { C }\end{array}$ & -0.72 & -2.48 & -2.9068 & -3.36 \\
\hline R_INC & $-1.75^{*}$ & 0.92 & -0.52 & -2.89 \\
\hline Keter & an & $\begin{array}{l}\text { : } * * *, \\
\text { untuk } \alpha \\
\text { persen, } \mathrm{d}\end{array}$ & $\begin{array}{l}* \text { nila } \\
1 \text { pers } \\
10 \text { pers }\end{array}$ & kritis \\
\hline
\end{tabular}

Dari kelima variabel pada Tabel 6 terlihat bahwa hanya variabel REER saja yang stasioner di level, selebihnya stasioner di first difference. Estimasi pada model VAR akan dilakukan dengan menggunakan data dalam bentuk first difference untuk semua variabel kecuali REER. Untuk variabel yang di ubah kedalam bentuk differencing akan diberi simbol D pada awal nama variabel sebagai contoh CA menjadi DCA. Untuk data REER dan R_INC diestimasi dalam bentuk logaritma.

\section{Penetapan Lag Optimal}

Estimasi VAR sangat peka terhadap panjang lag yang digunakan. Oleh karena itu, setelah dilakukan uji stasioneritas data maka langkah berikutnya adalah menentukan lag maksimum dan optimum. Dari hasil estimasi lag maksimum untuk model yang digunakan yaitu 22. Hal ini dilakukan karena ketika model diestimasi dengan lag 23 maka model yang dihasilkan bersifat tidak stabil terlihat dari adanya nilai Roots of Characteristic Polynomial yang melebihi angka 1. Namun jika diestimasi pada lag 22 nilai Roots of Characteristic Polynomial akan kurang dari 1. Sedangkan lag optimum yang digunakan dalam model ini yaitu lag 2 . Kriteria yang digunakan dalam pemilihan lag ini yaitu menggunakan FPE (Final Predictor Error).

\section{Hubungan Fleksibilitas Nilai Tukar dengan Penyesuaian Neraca Transaksi Berjalan}

\section{Analisis Model VAR}

Perilaku dinamis di dalam model VAR dapat dilihat dengan menggunakan Impulse Response Function (IRF) yang bekerja dengan cara melihat bagaimana variabel endogen bereaksi terhadap sebuah guncangan dalam variabel itu sendiri 
ataupun variabel endogen lainnya. Hal ini sesuai dengan Enders (2000) di mana cara yang paling baik untuk mencirikan struktur dinamis dalam model adalah dengan menganalisa respon dari model terhadap guncangan. Hasil impulse response dari permodelan VAR diukur dengan 1-standar deviasi.

Sumbu horizontal merupakan waktu dalam periode triwulan ke depan setelah terjadinya shock, sedangkan sumber vertikal adalah nilai respon. Secara mendasar dalam analisis ini akan diketahui respon positif atau negatif dari suatu variabel terhadap variabel lainnya. Respon tersebut dalam jangka pendek biasanya cukup signifikan dan cenderung berubah. Dalam jangka panjang respon cenderung konsisten dan terus mengecil. Impulse Response Function memberikan gambaran bagaimana respon dari suatu variabel di masa mendatang jika terjadi gangguan pada satu variabel lainnya. Untuk memudahkan interpretasi, dampak perubahan neraca transaksi berjalan yang diakibatkan oleh shock dari nilai tukar disajikan dalam bentuk grafik pada gambar-gambar di bawah ini dalam 10 periode.

1. Hasil Impulse Response Nilai Tukar terhadap Neraca Transaksi Berjalan

Jika dilihat respons nilai tukar terhadap neraca transaksi berjalan pada Gambar 3 terlihat bahwa adanya guncangan pada nilai tukar akan direspon negatif oleh neraca transaksi berjalan hingga periode kedua dengan kisaran nilai respons sebesar -0.02, kemudian akan naik kembali selang satu periode dan kemudian akan turun kembali, terlihat bahwa adanya kenaikan (apresiasi) pada nilai tukar tidak akan direspon dalam jangka waktu yang lama oleh neraca transaksi berjalan.
Response of DCA to REER

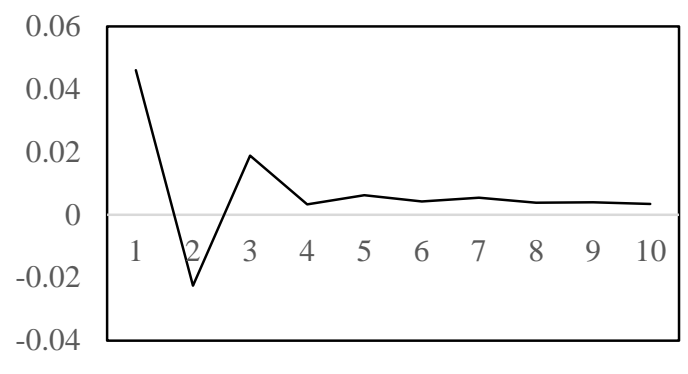

Gambar 3 Hasil Impulse Response Nilai

Tukar terhadap Neraca

Transaksi Berjalan

Persistensi pada neraca transaksi berjalan apabila defisit akan menyebabkan currency crisis krisis sedangkan apabila neraca transaksi berjalan dibiarkan untuk surplus secara terus menerus maka akan mendorong terciptanya kenaikan harga (inflasi) dan meningkatnya jumlah hutang luar negeri pemerintah Indonesia.

\section{Hasil Impulse Response Nilai Tukar terhadap Neraca Transaksi Berjalan}

Gambar 4 berikut merupakan hasil impulse respons nilai tukar terhadap neraca transaksi berjalan. Adanya perbaikan kondisi neraca transaksi berjalan akan menyebabkan nilai tukar terapresiasi kemudian pada periode kedua nilai tukar akan terdepresiasi dari besaran respon 0.5 hingga ke 0.2. Jika dilihat dari hasil impulse response function pada Gambar 3 dan 4, keduanya sesuai dengan teori yang banyak dibahas di dalam textbook, di mana adanya peningkatan dalam nilai tukar apresiasi riil akan memperburuk kondisi neraca transaksi berjalan dan adanya peningkatan neraca transaksi berjalan akan menyebabkan penurunan terhadap nilai tukar (depresiasi riil). 


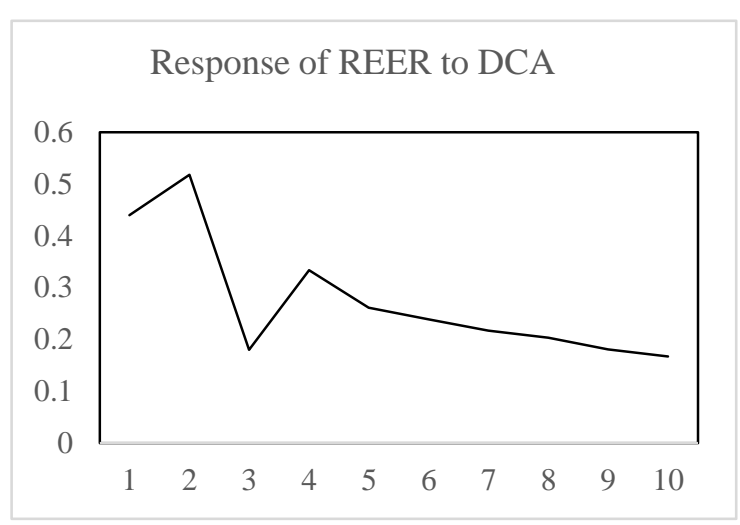

Gambar 4 Hasil Impulse Response Nilai

Tukar terhadap Neraca

Transaksi Berjalan

\section{Analisis Model Threshold VAR}

Salah satu tujuan dalam penelitian ini adalah untuk mengestimasi hubungan bilateral antara nilai tukar (REER) dan neraca transaksi berjalan (CA) yang bergantung pada rezim nilai tukar. Pemilihan variabel REER sebagai threshold didasari oleh dua alasan yang pertama nilai tukar riil bertanggungjawab pada penyesuaian CA yang kedua pada jangka panjang nilai tukar riil dan nominal memiliki perilaku yang sama. Tabel 5 di bawah ini menampilkan hasil korelasi antara $\mid \Delta \%$ REER $\mid$ dan empat klasifikasi rezim nilai tukar yang digunakan.

Tabel 5 Hasil Uji Korelasi antara $\mid \Delta$ persen REER| dengan Empat Klasifikasi Rezim Nilai Tukar

\begin{tabular}{rrrrrrr}
\hline & \multicolumn{1}{c}{ (1)| } & (2) & (3) & (4) & (5) \\
\hline (1) & 1 & & & & \\
$(2)$ & 0.51 & 1 & & & \\
$(3)$ & -0.06 & -0.116 & 1 & & \\
$(4)$ & -0.13 & -0.32 & -0.33 & 1 & \\
$(5)$ & 0.713 & 0.28 & -0.33 & 0.413 & 1 \\
\hline
\end{tabular}

Ket : (1) $\mid \Delta \%$ REER $\mid$
(2) IMF_CLASS
(3) KS_CLASS
(4) LY_CLASS
(5) RR_CLASS

Hasil uji korelasi memperlihatkan bahwa koefisien uji korelasi memiliki nilai yang rendah bahkan ada koefisien korelasi yang negatif. Koefisien korelasi yang paling besar dengan $\mid \Delta \%$ REER $\mid$ yaitu klasifikasi RR dengan nilai 0.71 . Hal ini mengindikasikan bahwa variabel threshold ditentukan berdasarkan nilai tukar riil sedangkan klasifikasi rezim nilai tukar ditentukan berdasarkan nilai tukar nominal. Untuk menentukan nilai threshold dapat diperoleh dengan kriteria nilai loglikelihood yang terbesar. Dari Tabel 6 terlihat bahwa nilai loglikelihood terbesar terdapat pada threshold indicator dengan nilai 27.7059. Selain menggunakan nilai loglikelihood. Pemilihan nilai threshold juga dapat didasarkan dengan berbagai kriteria pemilihan lain seperti AIC, SC dan HQC, di mana nilai threshold yang terpilih berdasarkan nilai kriteria terkecil.

Tabel 6 Hasil Uji Threshold

\begin{tabular}{|c|c|}
\hline $\begin{array}{l}\text { Threshold } \\
\text { Indicator }\end{array}$ & $\begin{array}{c}\text { Loglikelihood } \\
\text { Value }\end{array}$ \\
\hline 5.3195 & 330.4576 \\
\hline 6.6435 & 331.3341 \\
\hline 7.5899 & 331.2697 \\
\hline 7.6364 & 331.3198 \\
\hline 11.0585 & 330.7637 \\
\hline 11.6971 & 327.7045 \\
\hline 12.8042 & 329.8497 \\
\hline 17.1749 & 333.0769 \\
\hline 18.4114 & 333.2063 \\
\hline 18.6947 & 329.2983 \\
\hline 27.7059 & 341.5915 \\
\hline $\begin{array}{l}\text { Uji th } \\
\text { dilakukan p } \\
\text { threshold it } \\
\text { berdasarkan } \mathrm{d} \\
\text { ini akan me } \\
\text { bagian. Data } \\
\text { 27.7059 akan } \\
\text { low regime se } \\
\text { berada di at }\end{array}$ & $\begin{array}{l}\text { hanya dapat } \\
\text { ta level, karena } \\
\text { akan disortir } \\
\text { al. Nilai threshold } \\
\text { lata menjadi dua } \\
\text { yang di bawah } \\
\text { mpokan ke dalam } \\
\text { data REER yang } \\
\text { threshold akan }\end{array}$ \\
\hline
\end{tabular}


dikelompokan ke dalam high regime. Setelah mendapatkan nilai threshold maka estimasi akan dilanjutkan menggunakan TVAR dengan impulse response sebagai rangkuman dari hasil perilaku dinamis antara nilai tukar dan neraca transaksi berjalan.

Dalam menganalisis TVAR pada penelitian ini menggunakan data dalam bentuk first difference di mana seperti yang telah dibahas pada bagian data generating process bahwa hanya data REER saja yang stasioner di level. Untuk mengkompensasi adanya uji threshold yang dilakukan di level. Hal ini juga dilakukan pada penelitian Altissimo dan Violante (2000) yang meneliti mengenai dinamika tak linear pada output dan tingkat penggangguran di Amerika Serikat menggunakan Threshold VAR, di mana kedua variabel tersebut tidak stasioner di level. Dalam jurnal penelitian dari mereka dijelaskan bahwa, langkah awal dalam melakukan spesifikasi model yaitu melakukan pemilihan antara menggunakan data level atau first difference. Standar pengujian akar unit dapat menjelaskan adanya autoregressive root di kedua variabel, namun adanya perilaku tak linear dapat menjadikan adanya teori asimptotik pada pengujian akar unit menjadi tidak valid. Hasil dari sistem TVAR diringkas ke dalam estimasi impulse response function di mana pada gambar kondisi low regime akan digabung dengan kondisi high regime.Kondisi low regime ditandai dengan garis putus-putus dan kondisi high regime ditandai dengan garis utuh. Hasil perilaku dinamis dari model TVAR dapat dilihat dari hasil impulse response yang di rangkum sebagai berikut :

\section{Hasil Impulse Response Nilai Tukar terhadap Neraca Transaksi Berjalan pada Model TVAR}

Gambar 5 merupakan grafik hasil impulse response $\mathrm{di}$ mana guncangan pada neraca transaksi berjalan akan di respons oleh nilai tukar. Pada kondisi low regime adanya kenaikan atau shock pada neraca transaksi berjalan akan menyebabkan nilai tukar mengalami depresiasi ditandai dengan kenaikan nilai respons kemudian pada periode kedua nilai tukar akan mengalami apresiasi (nilai respons bergerak turun).

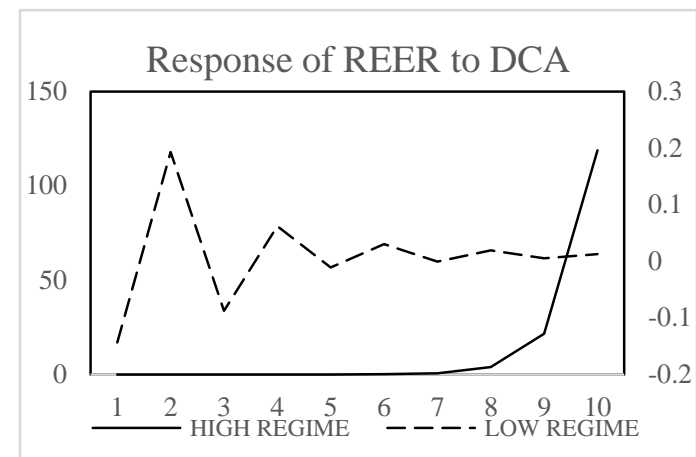

Gambar 3 Hasil Impulse Response Nilai Tukar terhadap Neraca Transaksi Berjalan pada Model TVAR

Sama halnya dengan penjelasan pada impulse response pertama dan kedua bahwa untuk kondisi high regime nilai respons akan persisten meningkat sehingga nilai respons tidak stabil. Dengan kata lain jika adanya perbaikan pada kondisi neraca transaksi berjalan akan diikuti oleh depresiasi secara terus menerus. Kondisi ini tidak mungkin terjadi karena akan membahayakan perekonomian. 


\section{Hasil Impulse Response Neraca Transaksi Berjalan terhadap Nilai Tukar pada Model TVAR}

Gambar 6 merupakan hasil impulse response pada neraca transaksi berjalan terhadap guncangan pada nilai tukar. merupakan hasil impulse response pada neraca transaksi berjalan terhadap guncangan pada nilai tukar. Terlihat adanya guncangan pada nilai tukar (depresiasi) akan direspons dengan surplus neraca transaksi berjalan hingga setengah periode (setara dengan satu setengah bulan). Kemudian periode berikutnya neraca transaksi berjalan akan mengalami defisit.

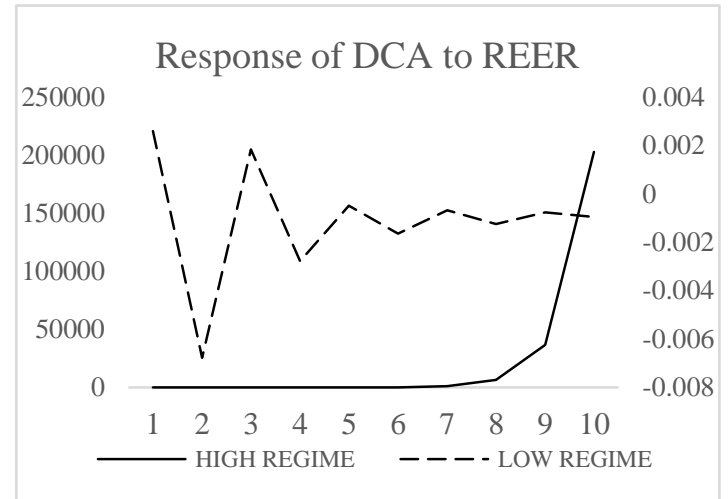

\section{Gambar 4 Hasil Impulse Response Neraca Transaksi Berjalan terhadap Nilai Tukar pada Model TVAR}

Defisit neraca transaksi berjalan juga akan terjadi sekitar satu setengah bulan, kemudian seterusnya kedua kondisi tersebut akan saling bergantian terjadi, hingga respons mendekati angka nol (respon tidak persisten). Dari hasil impulse response juga terlihat bahwa dampak terbesar dari adanya guncangan akan pada triwulan pertama. Sedangkan pada kondisi high regime, hasil impulse response ini tidak stabil mengingat nilai respons persisten terus mengalami peningkatan.

Dari kedua rezim dapat disimpulkan bahwa penyesuaian terhadap perubahan nilai tukar terjadi lebih cepat pada kondisi low regime dan bukan terjadi di high regime. Pada kondisi high regime, respon yang diberikan terhadap guncangan nilai tukar membutuhkan waktu hingga periode kedelapan dengan nilai respons yang tidak stabil. Jika hal ini terjadi maka kondisi neraca transaksi berjalan akan semakin memburuk sebelum terjadinya proses perbaikan. Hal ini sekali memberikan justifikasi bahwa di Indonesia, Friedman Hyphotesis berlaku hanya jika perubahan nilai tukar berada dalam kondisi low regime atau perubahan nilai tukar kurang dari 27.7059 (nilai threshold). Jika perubahan melebihi angka 27.7059 maka setiap kebijakan yang dijalankan berkaitan dengan nilai tukar tidak akan efektif memberikan hasil perbaikan terhadap sasaran kebijakan.

\section{Analisis Model Threshold VAR dengan Menggunakan Klasifikasi Rezim Nilai Tukar yang Berbeda}

Tahapan yang sama akan dilakukan dalam mengestimasi analisis Threshold VAR dengan menggunakan klasifikasi rezim nilai tukar yang berbeda. Dari hasil uji korelasi sebelumnya terpilih bahwa klasifikasi nilai tukar RR memiliki korelasi yang paling kuat dengan REER yaitu sebesar 0.71 , sehingga klasifikasi RR terpilih sebagai variabel threshold dalam analisis model Threshold VAR ini. Sebelum ke tahap estimasi, perlu dilakukan adanya penentuan nilai threshold dari threshold indicator yang telah ditentukan. 
Tabel 7 Hasil Uji Threshold dengan Klasifikasi RR

\begin{tabular}{cc}
\hline $\begin{array}{c}\text { Threshold } \\
\text { Indicator }\end{array}$ & $\begin{array}{c}\text { Loglikelihood } \\
\text { Value }\end{array}$ \\
\hline 3 & 343.646 \\
3 & 343.646 \\
3 & 343.646 \\
3 & 343.646 \\
3 & 343.646 \\
5 & 334.319 \\
5 & 334.319 \\
\hline
\end{tabular}

Dari hasil uji threshold diperoleh bahwa nilai threshold nya yaitu 3, dengan nilai loglikelihood 334.646 yang merupakan nilai loglikelihood terbesar. Setelah melakukan uji threshold kemudian diestimasi untuk memperoleh estimasi pada low regime dan high regime yang dirangkum dalam hasil impulse response (Gambar $7-8$ ), di mana nilai 3 meliputi nilai tukar dengan kriteria sebagai berikut :

1. Pre announced crawling band dengan kisaran nilai lebih besar atau sama dengan $+/-2 \%$.

2. De facto crawling band dengan kisaran nilai lebih kecil atau sama dengan $+/-5 \%$

3. Moving band dengan kisaran nilai lebih kecil atau sama dengan $+/-2 \%$

\section{Managed floating}

Nilai threshold 3 akan membagi sampel penelitian ini menjadi dua bagian di mana klasifikasi nilai tukar di atas 3 mengindikasikan nilai tukar dengan variabilitas tinggi (high regimelfloaters) sedangkan klasifikasi nilai tukar di bawah 3 mengindikasikan nilai tukar dengan variabilitas yang rendah (low regime/non-floaters).
1. Hasil Impulse Response Nilai Tukar terhadap Neraca Transaksi Berjalan pada Model TVAR dengan Variabel Threshold Klasifikasi RR

Gambar 7 merupakan hasil impulse response di mana guncangan pada neraca transaksi berjalan akan di respons pada nilai tukar. Terlihat perbedaan dampak pada gambar di mana bahwa hasil impulse pada kondisi low regime, adanya perbaikan pada kondisi neraca transaksi berjalan akan di respons dengan adanya depresiasi nilai tukar dalam kurun waktu yang cukup lama yaitu hingga periode ketiga, kemudian nilai tukar akan mengalami apresiasi hanya satu periode kemudian akan terdepresiasi lagi dalam kurun waktu 2 periode.

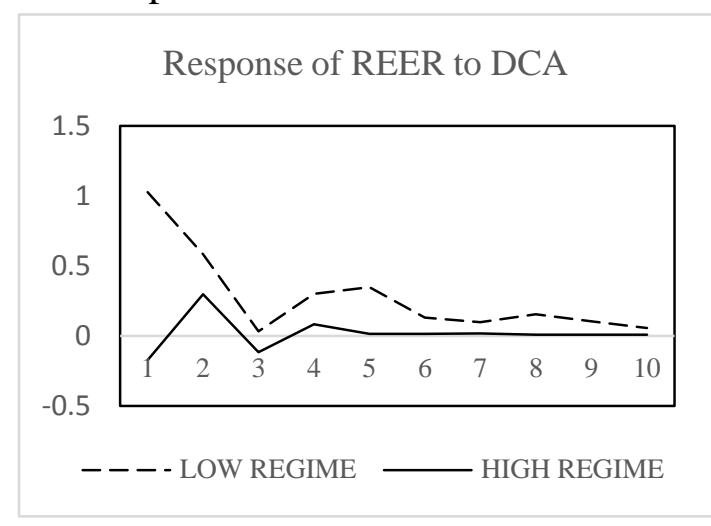

Gambar 5 Hasil Impulse Response Nilai Tukar terhadap Neraca Transaksi Berjalan pada Model TVAR dengan Variabel Threshold Klasifikasi RR

Sedangkan pada kondisi high regime, impulse response lebih dapat memperlihatkan penyesuaian terhadap perubahan nilai tukar dengan proporsi periode yang seimbang, di mana adanya depresiasi dan apresiasi masing masing sama sama terjadi selama selang satu periode. 
2. Hasil Impulse Response Neraca Transaksi Berjalan terhadap Nilai Tukar pada Model TVAR dengan Variabel Threshold Klasifikasi RR

Gambar 8 merupakan hasil impulse response pada neraca transaksi berjalan terhadap guncangan pada nilai tukar. Pada kondisi low regime, adanya guncangan pada nilai tukar (depresiasi) akan direspons dengan nilai neraca transaksi berjalan yang defisit hingga enam triwulan (waktu yang terbilang cukup lama untuk mengalami suatu defisit neraca transaksi berjalan/potensi currency crisis).

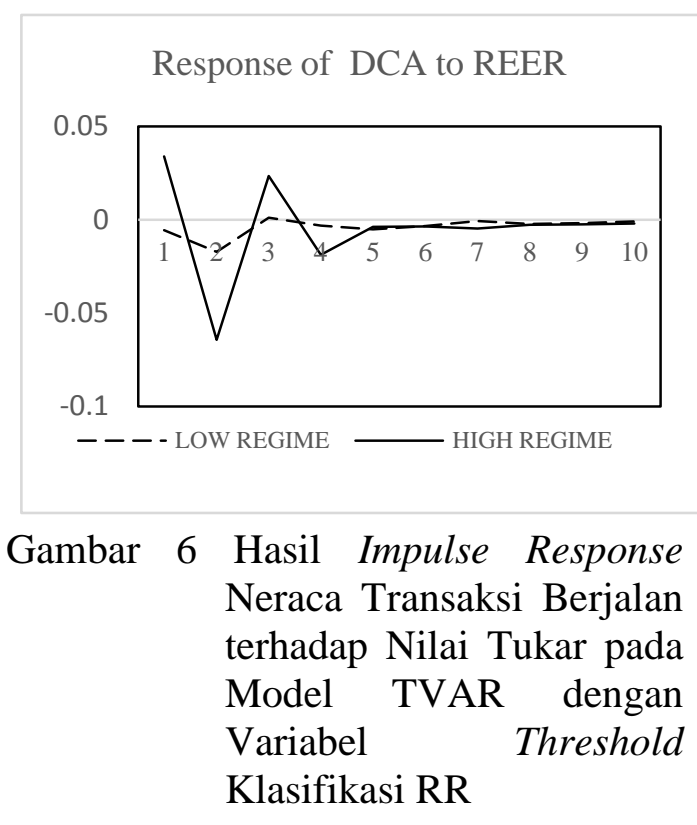

Sedangkan pada high regime, adanya depresiasi pada nilai tukar akan menyebabkan neraca transaksi berjalan surplus hingga kira-kira satu bulan setelah terjadinya shock atau guncangan kemudian neraca transaksi berjalan mengalami defisit, dan kemudian akan direspon secara konstan mendekati nol mulai dari periode keempat. Dari hasil impulse dapat terlihat jika penyesuaian neraca transaksi berjalan lebih baik terjadi di kondisi high regime. Hal ini dapat mendukung adanya Friedman
Hyphothesis, di mana adanya fleksibilitas nilai tukar berpengaruh positif pada penyesuasian transaksi berjalan.

Jika dibandingkan dari hasil analisis Threshold VAR dengan variabel threshold REER dan klasifikasi rezim nilai tukar $R R$ memperlihatkan hasil yang berbeda dimana, hal ini dikarenakan adanya perbedaan konsep antara variabel threshold REER dan klasifikasi RR. Variabel threshold REER merupakan nilai absolut dari perubahan real effective exchange rate.

Tabel 8 Perbedaan hasil TVAR pada masing-masing variabel threshold

\begin{tabular}{ccc}
\hline No. & $\begin{array}{c}\text { Variabel } \\
\text { Threshold }\end{array}$ & Hasil \\
\hline 1. & REER & Low regime
\end{tabular}

2. Klasifikasi RR High regime

Menurut McCallum (1989), fluktuasi semakin besar (variabilitas nilai tukar) terlihat pada kisaran tahun 1973 dimulai ketika Amerika Serikat mengalami pergeseran nilai tukar dari fixed menjadi free float. Sehingga dapat disimpulkan jika perubahan nilai tukar memiliki perubahan yang cukup besar memperlihatkan adanya perubahan rezim yang cukup drastis. Dengan estimasi TVAR, nilai threshold dengan variabel REER yaitu 27.7059 terjadi pada periode 1998Q1. Menurut studi yang dilakukan Adiningsih et al. (2008) menyatakan bahwa pada tahun 1997 rezim nilai tukar yang dianut oleh Indonesia berubah dari rezim nilai tukar tetap menjadi rezim nilai tukar mengambang. Jika dilihat pada Tabel 
13, adanya nilai REER pada tahun 1998

- 2013 secara berfluktuasi memiliki nilai perubahan yang relatif kecil jika dibandingkan nilai threshold yang diperoleh.

Tabel 9 Keterangan mengenai klasifikasi nilai tukar RR

\begin{tabular}{|c|c|}
\hline Kode & Keterangan \\
\hline 1 & No separate legal tender \\
\hline 1 & Pre announced peg \\
\hline 1 & $\begin{array}{l}\text { Pre announced horizontal band that is } \\
\text { narrower than or equal to }+1-2 \%\end{array}$ \\
\hline 2 & De facto peg \\
\hline 2 & Pre announced crawling peg \\
\hline 2 & $\begin{array}{l}\text { Pre announced crawling band that is } \\
\text { narrower than or equal to }+/-2 \%\end{array}$ \\
\hline 2 & De factor crawling peg \\
\hline 2 & $\begin{array}{l}\text { De facto crawling band that is narrower than } \\
\text { or equal to }+/-2 \%\end{array}$ \\
\hline 3 & $\begin{array}{l}\text { Pre announced crawling band that is wider } \\
\text { than or equal to }+/-2 \%\end{array}$ \\
\hline 3 & $\begin{array}{l}\text { De facto crawling band that is narrower than } \\
\text { or equal to }+1-5 \%\end{array}$ \\
\hline 3 & $\begin{array}{l}\text { Moving band that is narrower than or equal to } \\
+/-2 \% \text { (i.e., allows for both appreciation and } \\
\text { depreciation over time) }\end{array}$ \\
\hline 3 & Managed floating \\
\hline 4 & Freely floating \\
\hline 5 & Freely falling \\
\hline 6 & $\begin{array}{l}\text { Dual market in which parallel market data is } \\
\text { missing. }\end{array}$ \\
\hline
\end{tabular}

Dalam estimasi yang dilakukan sebelumnya telah dikelompokan variabilitas nilai tukar dengan nilai threshold sebagai batasan sesuai dengan (Kim dan You, 2013), di mana variabilitas nilai tukar dengan nilai rendah dikategorikan ke dalam low regimel non-floaters sedangkan variabilitas dengan nilai yang tinggi (>27.7059) dikategorikan ke dalam high regimel floaters. Hal ini mengindikasikan jika tidak serta merta adanya variabilitas dengan nilai yang tinggi merupakan indikasi bahwa suatu negara menganut rezim nilai tukar yang floater atau flexible.

Nilai variabilitas sangat tergantung pada rezim nilai tukar yang dianut sebelumnya. Sehingga hasil dari estimasi TVAR dengan variabel threshold REER, lebih menekankan pada sampai batasan mana nilai tukar di Indonesia diperbolehkan untuk mengalami perubahan.

Sedangkan jika dilihat dari variabel threshold, klasifikasi RR memiliki kisaran nilai antara 1 sampai 5 di mana semakin besarnya angka menunjukan bahwa suatu negara menganut nilai tukar yang semakin fleksibel.

Dengan perolehan nilai threshold 3, maka sampel pada penelitian ini akan dibagi menjadi dua di mana klasifikasi nilai tukar di atas 3 mengindikasikan nilai tukar dengan variabilitas tinggi (high regimel floaters) sedangkan klasifikasi nilai tukar di bawah 3 mengindikasikan nilai tukar dengan variabilitas yang rendah (low regime/non-floaters). Sehingga estimasi pada Threshold VAR dengan variabel threshold klasifikasi RR dapat menunjukan bahwa fleksibilitas nilai tukar dapat membantu penyesuaian neraca transaksi berjalan suatu negara apabila negara tersebut menganut rezim nilai tukar yang mengarah ke nilai tukar 
fleksibel (nilai tukar RR dengan kode 3 - 6/ intermediate regimes dan flexible regimes) lihat halaman 6 pada tinjauan pustaka, serta klasifikasi RR (de facto classification) dapat merefleksikan nilai tukar aktual di Indonesia.

\section{SIMPULAN DAN SARAN}

\section{Simpulan}

1. Klasifikasi rezim nilai tukar secara de facto yaitu klasifikasi RR dapat merefleksikan nilai tukar aktual di Indonesia.

2. Dengan menggunakan estimasi tak linear dengan menggunakan variabel threshold REER maupun klasifikasi RR, diperoleh hasil bahwa Friedman Hyphotesis berlaku di Indonesia. Dengan syarat, Indonesia menganut rezim nilai tukar dengan kode 3 - 6 pada klasifikasi RR atau nilai tukar yang termasuk kategori intermediate regime atau flexible regime, serta perubahan nilai tukar tidak melebihi batas threshold 27.7059.

\section{Saran}

1. Adanya pengaruh fleksibilitas nilai tukar dapat memperbaiki penyesuaian neraca transaksi berjalan apabila nilai tukar Indonesia berada pada perubahan nilai tukar yang tidak lebih dari 27.7059. Oleh karena itu sebagai otoritas moneter, Bank Indonesia perlu menjaga agar perubahan nilai tukar berada di rentang kurang dari atau sama dengan 27.7059. Jika perubahan melebihi angka 27.7059 maka setiap kebijakan yang dijalankan berkaitan dengan nilai tukar tidak akan efektif memberikan hasil perbaikan terhadap sasaran kebijakan. Untuk dapat membantu sistem transmisi jalur nilai tukar maka pemerintah dapat melakukan peningkatan kualitas produksi ekspor dengan memaksimalkan penggunaan bahan baku dalam negeri dan tidak terlalu memanfaatkan harga produk murah dari adanya depresiasi untuk memperbaiki kinerja ekspor, mengurangi pengeluaran pemerintah, melakukan pemotongan pajak serta meningkatkan suku bunga.

2. Struktur foreign asset di Indonesia harus secara dominan terdiri dari mata uang asing dan struktur domestic liabilities mayoritas harus terdiri dari mata uang domestik atau rupiah supaya fleksibilitas nilai tukar dapat mempengaruhi sektor eksternal terutama transaksi berjalan. Menurut McCallum (1989) nilai tukar merupakan variabel eksogen yang dapat mempengaruhi variabel lain. Keuntungan dalam menggunakan nilai tukar sebagai alat transmisi karena adanya kemudahan dalam mengendalikan nilai tukar.

\section{DAFTAR PUSTAKA}

Adhiningsih S et al. 1998. Perangkat Analisis dan Teknik Analisis Investasi di

Pasar Modal Indonesia. Jakarta (ID) : PT Bursa Efek Jakarta

Altissimo, F, Violante GL. The Nonlinear Dynamics of Output and

Unemployment in the U.S. Wiley Online Library

Brooks C. 2002. Introductory Econometrics for Finance. Cambridge (UK) : Cambridge University Press.

Calvo G, Reinhart C. 2002. Fear of floating. Quartely Journal of Economics 177, no 2 : 379-408. 
Chinn MD, Wei SJ. 2008. A faith-based initiative mees the evidence : does flexible exchange rate regime really facilitate current account adjustment?. Forthcoming, Review of Economics and Statistics.

Chowdury A, Hossain A. 2001. Open Economy : Macro-Economics for Developing Countries. Massachusetts (US) : Edward Elgar Publishing Inc

Decressin J, Stavrev E. 2009. Current account in a currency union. IMF Working Paper 2009 no 127.

Donald R. 2007. Exchange Rate Economics Theories and Evidence. New York (US) : Routledge Taylor \& Francis Group.

Dornbusch, R. (1980). Open Economy Macroconomics. New York: NY. Basic Books.

Duttagupta R, Fernandez G, Karacadag C. 2005. Moving to a flexible exchange rate how, when, and how fast?. IMF Economic Issues 38.

Enders W. 2004. Applied Econometric Time series Second Edition. New York (US) : University of Alabama.

. Friedman M. 1953. The Case for flexible exchange rate. Essay in Positive Economics (pp. 157-2013). University of Chicago Press.

Genberg H, Swoboda A. 2004. Exchange rate regimes : does what countries say matter ?. Graduate Institute of International Studies Working paper, Geneva.

Gujarati D. 2004. Basic Econometrics Fourth Edition. Boston (US) : The McGraw-Hill Companies.

Herrmann S. 2009. Do we really know that flexible exchange rates facilitate current account adjustment? Some new empirical evidence for CEE countries. Discussion Paper Series 1: Economic Studies No 22/2009.

Kim Y, You Y. 2013. Exchange rate flexibility and current account adjustment: a threshold VAR Analysis.

Klein MW, Shambaugh JC. 2006. The nature of exchange rate. NBER Working Paper No 12729.

Levy Yeyati E, Sturzenegger F. 2003. To float or to fix: evidence on the impact of exchange rate regimes on growth. American Economic Review, 93,11731193.

Levy Yeyati E, Sturzenegger F. 2005. Classifying exchange rate regimes : deeds vs words. European Economic Review 49 no 3: 1173-93.

McCallum B. 1989. Monetary Economics Theory and Policy. New York (US) : Macmillan Publishing Company.

Milesi-Ferretti G.M, Razin A. 1996. Current account sustainability. Princeton Studies in International Finance No. 81 Oktober 1996, Princeton University, New Jersey.

Nugroho et al. 2012. Perilaku dan dampak capital reversal serta current account threshold terhadap Nilai Tukar Rupiah. Working Paper WP/05/2012. Bank Indonesia.

Pohan A. 2008. Kerangka Kebijakan Moneter dan Implementasinya di Indonesia. Jakarta (ID) : PT Rajawali Grafindo Persada.

Reinhart C, Rogoff K. 2004. The modern history of exchange rate arrangements : a a reinterpretation. Quarterly 
Journal of Economics, 199,1 48.

Sekkat K. 1997. Exchange rate variability and EU trade. Final Report to the Commission of the EU, Second Revision.

Sozovska A. 2004. Exchange rate regimes in transition economies. Discussion Paper USAID Fiscal Reform Project.

Thomas R L. 1997. Modern Econometrics - an Introduction. Manchester (UK) : Manchester Metropolitan University.
Elektronik

Bank Indonesia. 1999. Laporan

Tahunan 1998/1999. [http://bi.go.id]. [di unduh 6 Maret 2014]

Bank Indonesia. 2009. Outlook Ekonomi Indonesia 2009-2014, Edisi Januari 2009. [http://bi.go.id]. [di unduh 6 Maret 2014]

Ecthink. 2009. Anomali pemulihan ekonomi global : Ketidakseimbangan Global. [www.ecthink.net]. [Diunduh 6 Maret 2014]

www.bappenas.go.id/index.php/downlo ad_file/view/8983/1748/ 


\section{Lampiran}

\section{Pemilihan Lag pada Analisis VAR}

\begin{tabular}{|c|c|c|c|c|c|c|}
\hline Lag & LogL & LR & FPE & AIC & SC & HQ \\
\hline & & & & & & \\
\hline 0 & 316.2304 & NA & $9.24 \mathrm{E}-07$ & -8.21948 & -7.97228 & -8.12077 \\
\hline 1 & 327.2407 & 20.25909 & $7.66 \mathrm{E}-07$ & -8.40642 & $-8.035622^{*}$ & $-8.258364^{*}$ \\
\hline 2 & 332.0438 & 8.581395 & $\mathbf{7 . 5 1 e - 0 7 ^ { * }}$ & $-8.427834^{*}$ & -7.93344 & -8.23043 \\
\hline 3 & 332.5079 & 0.804578 & $8.26 \mathrm{E}-07$ & -8.33355 & -7.71555 & -8.08679 \\
\hline 4 & 338.9614 & $10.84180^{*}$ & $7.76 \mathrm{E}-07$ & -8.39897 & -7.65737 & -8.10286 \\
\hline 5 & 341.2931 & 3.792827 & $8.14 \mathrm{E}-07$ & -8.35448 & -7.48929 & -8.00902 \\
\hline 6 & 341.4895 & 0.309148 & $9.05 \mathrm{E}-07$ & -8.25306 & -7.26426 & -7.85824 \\
\hline 7 & 342.0251 & 0.814072 & $9.98 \mathrm{E}-07$ & -8.16067 & -7.04828 & -7.7165 \\
\hline 8 & 343.0276 & 1.470243 & $1.09 \mathrm{E}-06$ & -8.08074 & -6.84474 & -7.58722 \\
\hline
\end{tabular}

* indicates lag order selected by the criterion

LR: sequential modified LR test statistic (each test at 5 persen level)

FPE: Final prediction error

AIC: Akaike information criterion

SC: Schwarz information criterion

HQ: Hannan-Quinn information criterion

\section{Hasil Pemilihan Nilai Threshold dengan REER sebagai Threshold} Indicator

\begin{tabular}{|c|c|c|c|c|}
\hline Threshold & \multirow{2}{*}{ LLL } & \multirow{2}{*}{ AIC } & \multirow{2}{*}{ SBC } & \multirow{2}{*}{ HQC } \\
\hline Indicator & & & & \\
\hline 0.0263 & 277.3882 & -6.2565 & -5.5470 & -5.9719 \\
\hline 0.0349 & 322.7214 & -7.3758 & -6.6664 & -7.0912 \\
\hline 0.0425 & 322.7601 & -7.3768 & -6.6673 & -7.0921 \\
\hline 0.0427 & 322.7913 & -7.3776 & -6.6681 & -7.0929 \\
\hline 0.0808 & 323.2789 & -7.3896 & -6.6801 & -7.1050 \\
\hline 0.1191 & 323.3225 & -7.3907 & -6.6812 & -7.1060 \\
\hline 0.1472 & 322.8511 & -7.3790 & -6.6696 & -7.0944 \\
\hline 0.1499 & 323.8832 & -7.4045 & -6.6951 & -7.1199 \\
\hline 0.1892 & 322.8580 & -7.3792 & -6.6697 & -7.0946 \\
\hline 0.2038 & 323.0613 & -7.3842 & -6.6748 & -7.0996 \\
\hline 0.3026 & 324.0733 & $\begin{array}{l}-7.4092 \\
\end{array}$ & -6.6997 & -7.1246 \\
\hline 0.3280 & 324.2233 & -7.4129 & -6.7035 & -7.1283 \\
\hline 0.3348 & 325.2025 & -7.4371 & -6.7276 & -7.1525 \\
\hline
\end{tabular}




\begin{tabular}{|c|c|c|c|c|}
\hline 0.3487 & 325.2887 & -7.4392 & -6.7298 & -7.1546 \\
\hline 0.3523 & 325.5862 & -7.4466 & -6.7371 & -7.1619 \\
\hline 0.3833 & 325.7087 & -7.4496 & -6.7401 & -7.1650 \\
\hline 0.3886 & 325.6426 & -7.4480 & -6.7385 & -7.1633 \\
\hline 0.4006 & 326.1397 & -7.4602 & -6.7508 & -7.1756 \\
\hline 0.4427 & 326.7110 & -7.4743 & -6.7649 & -7.1897 \\
\hline 0.4798 & 326.6744 & -7.4734 & -6.7640 & -7.1888 \\
\hline 0.5012 & 326.7705 & -7.4758 & -6.7663 & -7.1912 \\
\hline 0.5172 & 326.1186 & -7.4597 & -6.7503 & -7.1751 \\
\hline 0.5464 & 326.0810 & -7.4588 & -6.7493 & -7.1741 \\
\hline 0.5468 & 327.5702 & -7.4956 & -6.7861 & -7.2109 \\
\hline 0.6141 & 326.7720 & -7.4759 & -6.7664 & -7.1912 \\
\hline 0.6157 & 326.5431 & -7.4702 & -6.7607 & -7.1856 \\
\hline 0.6333 & 325.5364 & -7.4453 & -6.7359 & -7.1607 \\
\hline 0.7512 & 325.5543 & -7.4458 & -6.7363 & -7.1611 \\
\hline 0.7608 & 325.2864 & -7.4392 & -6.7297 & -7.1545 \\
\hline 0.7807 & 325.4067 & -7.4421 & -6.7327 & -7.1575 \\
\hline 0.7826 & 325.2883 & -7.4392 & -6.7298 & -7.1546 \\
\hline 0.7829 & 324.5350 & -7.4206 & -6.7112 & -7.1360 \\
\hline 0.8971 & 324.5084 & -7.4200 & -6.7105 & -7.1353 \\
\hline 0.8980 & 324.8302 & -7.4279 & -6.7184 & -7.1433 \\
\hline 0.9417 & 324.8231 & -7.4277 & -6.7183 & -7.1431 \\
\hline 1.0158 & 324.6918 & -7.4245 & -6.7150 & -7.1398 \\
\hline 1.0646 & 325.3101 & -7.4398 & -6.7303 & -7.1551 \\
\hline 1.1985 & 324.9340 & -7.4305 & -6.7210 & -7.1458 \\
\hline 1.2561 & 324.6709 & -7.4240 & -6.7145 & -7.1393 \\
\hline 1.2894 & 324.6843 & -7.4243 & -6.7148 & -7.1397 \\
\hline 1.3218 & 327.6927 & -7.4986 & -6.7891 & -7.2139 \\
\hline 1.3528 & 327.7533 & -7.5001 & -6.7906 & -7.2154 \\
\hline 1.3626 & 329.4318 & -7.5415 & -6.8321 & -7.2569 \\
\hline 1.3874 & 328.9097 & -7.5286 & -6.8192 & -7.2440 \\
\hline 1.4517 & 328.8106 & -7.5262 & -6.8167 & -7.2415 \\
\hline 1.4626 & 331.0321 & -7.5810 & -6.8716 & -7.2964 \\
\hline 1.5393 & 331.1773 & -7.5846 & -6.8752 & -7.3000 \\
\hline 1.5650 & 331.1773 & -7.5846 & -6.8752 & -7.3000 \\
\hline 1.5916 & 331.2831 & -7.5872 & -6.8778 & -7.3026 \\
\hline 1.6164 & 330.9506 & -7.5790 & -6.8696 & -7.2944 \\
\hline 1.6208 & 329.5129 & -7.5435 & -6.8341 & -7.2589 \\
\hline 1.7032 & 329.5934 & -7.5455 & -6.8360 & -7.2609 \\
\hline 1.7278 & 329.8740 & -7.5524 & -6.8430 & -7.2678 \\
\hline 1.8484 & 328.4318 & -7.5168 & -6.8074 & -7.2322 \\
\hline 1.9177 & 330.5945 & -7.5702 & -6.8608 & -7.2856 \\
\hline 2.2066 & 330.3982 & -7.5654 & -6.8559 & -7.2807 \\
\hline
\end{tabular}




\begin{tabular}{|c|c|c|c|c|}
\hline 2.2503 & 330.6042 & -7.5705 & -6.8610 & -7.2858 \\
\hline 2.5685 & 330.2895 & -7.5627 & -6.8532 & -7.2781 \\
\hline 3.1286 & 329.9840 & -7.5552 & -6.8457 & -7.2705 \\
\hline 3.2574 & 330.1895 & -7.5602 & -6.8508 & -7.2756 \\
\hline 3.2798 & 331.1292 & -7.5834 & -6.8740 & -7.2988 \\
\hline 3.4640 & 329.4122 & -7.5410 & -6.8316 & -7.2564 \\
\hline 3.8429 & 329.2911 & -7.5381 & -6.8286 & -7.2534 \\
\hline 3.9211 & 328.7367 & -7.5244 & -6.8149 & -7.2397 \\
\hline 3.9332 & 328.2172 & -7.5115 & -6.8021 & -7.2269 \\
\hline 4.7639 & 328.7902 & -7.5257 & -6.8162 & -7.2410 \\
\hline 4.8913 & 328.7966 & -7.5258 & -6.8164 & -7.2412 \\
\hline 4.9301 & 328.8110 & -7.5262 & -6.8167 & -7.2415 \\
\hline 5.3195 & 330.4576 & -7.5669 & -6.8574 & -7.2822 \\
\hline 6.6435 & 331.3341 & -7.5885 & -6.8790 & -7.3038 \\
\hline 7.5899 & 331.2697 & -7.5869 & -6.8774 & -7.3023 \\
\hline 7.6364 & 331.3198 & -7.5881 & -6.8787 & -7.3035 \\
\hline 11.0585 & 330.7637 & -7.5744 & -6.8649 & -7.2898 \\
\hline 11.6971 & 327.7045 & -7.4989 & -6.7894 & -7.2142 \\
\hline 12.8042 & 329.8497 & -7.5518 & -6.8424 & -7.2672 \\
\hline 17.1749 & 333.0769 & -7.6315 & -6.9221 & -7.3469 \\
\hline 18.4114 & 333.2063 & -7.6347 & -6.9253 & -7.3501 \\
\hline 18.6947 & 329.2983 & -7.5382 & -6.8288 & -7.2536 \\
\hline 27.7059 & 341.5915 & -7.8418 & -7.1323 & -7.5571 \\
\hline
\end{tabular}

\section{Hasil Estimasi Threshold VAR}

\begin{tabular}{|c|c|c|c|c|c|c|}
\hline & \multirow{2}{*}{ D_CA } & \multirow{2}{*}{ REER } & T-RATIO & T-RATIO & PROB & PROB \\
\hline & & & D_CA & REER & D_CA & REER \\
\hline L1_D_CA & 5.8552 & 20.3149 & 3.5806 & 3.7383 & 0.0006 & 0.0003 \\
\hline L1_REER & 0.0407 & 0.3693 & 1.4127 & 3.8572 & 0.1617 & 0.0002 \\
\hline L2_D_CA & -2.7221 & 6.5543 & -1.3773 & 0.9979 & 0.1723 & 0.3214 \\
\hline L2_REER & -0.0220 & 0.6262 & -0.7188 & 6.1608 & 0.4744 & 0.0000 \\
\hline Threshold L1_D_CA & -6.2316 & -20.4586 & -3.7917 & -3.7459 & 0.0003 & 0.0003 \\
\hline Threshold L1_REER & -0.0381 & -0.0740 & -3.1613 & -1.8478 & 0.0022 & 0.0684 \\
\hline Threshold L2_D_CA & 2.5144 & -6.3729 & 1.2482 & -0.9520 & 0.2156 & 0.3440 \\
\hline Threshold L2_REER & 0.0154 & -0.0319 & 1.1068 & -0.6895 & 0.2718 & 0.4926 \\
\hline D_OPENC & -0.0007 & 0.5055 & -0.0220 & 4.8447 & 0.9825 & 0.0000 \\
\hline D_LINC & -0.0288 & -0.7234 & -0.3141 & -2.3771 & 0.7543 & 0.0199 \\
\hline D_FIN & 0.0131 & 0.0597 & 0.5144 & 0.7031 & 0.6084 & 0.4841 \\
\hline CONS & 0.0074 & 0.2325 & 0.1108 & 1.0422 & 0.9121 & 0.3005 \\
\hline
\end{tabular}




\section{Hasil Pemilihan Nilai Threshold dengan Klasifikasi RR sebagai Threshold Indicator}

\begin{tabular}{|c|c|c|c|c|}
\hline Threshold & \multirow{2}{*}{$\mathbf{L L L}$} & \multirow{2}{*}{$\mathbf{A I C}$} & \multirow{2}{*}{ SBC } & \multirow{2}{*}{ HQC } \\
\hline Indicator & & & & \\
\hline 2 & \#VALUE! & \#VALUE! & \#VALUE! & \#VALUE! \\
\hline 2 & \#VALUE! & \#VALUE! & \#VALUE! & \#VALUE! \\
\hline 2 & \#VALUE! & \#VALUE! & \#VALUE! & \#VALUE! \\
\hline 2 & \#VALUE! & \#VALUE! & \#VALUE! & \#VALUE! \\
\hline 2 & \#VALUE! & \#VALUE! & \#VALUE! & \#VALUE! \\
\hline 2 & \#VALUE! & \#VALUE! & \#VALUE! & \#VALUE! \\
\hline 2 & \#VALUE! & \#VALUE! & \#VALUE! & \#VALUE! \\
\hline 2 & \#VALUE! & \#VALUE! & \#VALUE! & \#VALUE! \\
\hline 2 & \#VALUE! & \#VALUE! & \#VALUE! & \#VALUE! \\
\hline 2 & \#VALUE! & \#VALUE! & \#VALUE! & \#VALUE! \\
\hline 2 & \#VALUE! & \#VALUE! & \#VALUE! & \#VALUE! \\
\hline 2 & \#VALUE! & \#VALUE! & \#VALUE! & \#VALUE! \\
\hline 2 & \#VALUE! & \#VALUE! & \#VALUE! & \#VALUE! \\
\hline 2 & \#VALUE! & \#VALUE! & \#VALUE! & \#VALUE! \\
\hline 2 & \#VALUE! & \#VALUE! & \#VALUE! & \#VALUE! \\
\hline 2 & \#VALUE! & \#VALUE! & \#VALUE! & \#VALUE! \\
\hline 2 & \#VALUE! & \#VALUE! & \#VALUE! & \#VALUE! \\
\hline 2 & \#VALUE! & \#VALUE! & \#VALUE! & \#VALUE! \\
\hline 3 & 343.64567 & -7.892486 & -7.183019 & -7.607839 \\
\hline 3 & 343.64567 & -7.892486 & -7.183019 & -7.607839 \\
\hline 3 & 343.64567 & -7.892486 & -7.183019 & -7.607839 \\
\hline 3 & 343.64567 & -7.892486 & -7.183019 & -7.607839 \\
\hline 3 & 343.64567 & -7.892486 & -7.183019 & -7.607839 \\
\hline 3 & 343.64567 & -7.892486 & -7.183019 & -7.607839 \\
\hline 3 & 343.64567 & -7.892486 & -7.183019 & -7.607839 \\
\hline 3 & 343.64567 & -7.892486 & -7.183019 & -7.607839 \\
\hline 3 & 343.64567 & -7.892486 & -7.183019 & -7.607839 \\
\hline 3 & 343.64567 & -7.892486 & -7.183019 & -7.607839 \\
\hline 3 & 343.64567 & -7.892486 & -7.183019 & -7.607839 \\
\hline 3 & 343.64567 & -7.892486 & -7.183019 & -7.607839 \\
\hline 3 & 343.64567 & -7.892486 & -7.183019 & -7.607839 \\
\hline 3 & 343.64567 & -7.892486 & -7.183019 & -7.607839 \\
\hline 3 & 343.64567 & -7.892486 & -7.183019 & -7.607839 \\
\hline 3 & 343.64567 & -7.892486 & -7.183019 & -7.607839 \\
\hline 3 & 343.64567 & -7.892486 & -7.183019 & -7.607839 \\
\hline 3 & 343.64567 & -7.892486 & -7.183019 & -7.607839 \\
\hline 3 & 343.64567 & -7.892486 & -7.183019 & -7.607839 \\
\hline 3 & 343.64567 & -7.892486 & -7.183019 & -7.607839 \\
\hline 3 & 343.64567 & -7.892486 & -7.183019 & -7.607839 \\
\hline
\end{tabular}




\begin{tabular}{|c|c|c|c|c|}
\hline 3 & 343.64567 & -7.892486 & -7.183019 & -7.607839 \\
\hline 3 & 343.64567 & -7.892486 & -7.183019 & -7.607839 \\
\hline 3 & 343.64567 & -7.892486 & -7.183019 & -7.607839 \\
\hline 3 & 343.64567 & -7.892486 & -7.183019 & -7.607839 \\
\hline 3 & 343.64567 & -7.892486 & -7.183019 & -7.607839 \\
\hline 3 & 343.64567 & -7.892486 & -7.183019 & -7.607839 \\
\hline 3 & 343.64567 & -7.892486 & -7.183019 & -7.607839 \\
\hline 3 & 343.64567 & -7.892486 & -7.183019 & -7.607839 \\
\hline 3 & 343.64567 & -7.892486 & -7.183019 & -7.607839 \\
\hline 3 & 343.64567 & -7.892486 & -7.183019 & -7.607839 \\
\hline 3 & 343.64567 & -7.892486 & -7.183019 & -7.607839 \\
\hline 3 & 343.64567 & -7.892486 & -7.183019 & -7.607839 \\
\hline 3 & 343.64567 & -7.892486 & -7.183019 & -7.607839 \\
\hline 3 & 343.64567 & -7.892486 & -7.183019 & -7.607839 \\
\hline 3 & 343.64567 & -7.892486 & -7.183019 & -7.607839 \\
\hline 3 & 343.64567 & -7.892486 & -7.183019 & -7.607839 \\
\hline 3 & 343.64567 & -7.892486 & -7.183019 & -7.607839 \\
\hline 3 & 343.64567 & -7.892486 & -7.183019 & -7.607839 \\
\hline 3 & 343.64567 & -7.892486 & -7.183019 & -7.607839 \\
\hline 3 & 343.64567 & -7.892486 & -7.183019 & -7.607839 \\
\hline 3 & 343.64567 & -7.892486 & -7.183019 & -7.607839 \\
\hline 3 & 343.64567 & -7.892486 & -7.183019 & -7.607839 \\
\hline 3 & 343.64567 & -7.892486 & -7.183019 & -7.607839 \\
\hline 3 & 343.64567 & -7.892486 & -7.183019 & -7.607839 \\
\hline 3 & 343.64567 & -7.892486 & -7.183019 & -7.607839 \\
\hline 3 & 343.64567 & -7.892486 & -7.183019 & -7.607839 \\
\hline 3 & 343.64567 & -7.892486 & -7.183019 & -7.607839 \\
\hline 3 & 343.64567 & -7.892486 & -7.183019 & -7.607839 \\
\hline 3 & 343.64567 & -7.892486 & -7.183019 & -7.607839 \\
\hline 3 & 343.64567 & -7.892486 & -7.183019 & -7.607839 \\
\hline 3 & 343.64567 & -7.892486 & -7.183019 & -7.607839 \\
\hline 3 & 343.64567 & -7.892486 & -7.183019 & -7.607839 \\
\hline 3 & 343.64567 & -7.892486 & -7.183019 & -7.607839 \\
\hline 3 & 343.64567 & -7.892486 & -7.183019 & -7.607839 \\
\hline 3 & 343.64567 & -7.892486 & -7.183019 & -7.607839 \\
\hline 3 & 343.64567 & -7.892486 & -7.183019 & -7.607839 \\
\hline 3 & 343.64567 & -7.892486 & -7.183019 & -7.607839 \\
\hline 3 & 343.64567 & -7.892486 & -7.183019 & -7.607839 \\
\hline 5 & 334.31886 & -7.662194 & -6.952728 & -7.377547 \\
\hline 5 & 334.31886 & -7.662194 & -6.952728 & -7.377547 \\
\hline
\end{tabular}


5. Hasil Estimasi Threshold VAR dengan Klasifikasi RR sebagai Threshold Indicator

\begin{tabular}{|l|c|c|c|c|c|c|}
\hline & \multirow{2}{*}{ D_CA } & \multirow{2}{*}{ REER } & T-RATIO & T-RATIO & PROB & PROB \\
\cline { 1 - 4 } & & & D_CA & REER & D_CA & REER \\
\hline L1_D_CA & -0.488 & -0.172 & -3.568 & -0.337 & 0.001 & 0.737 \\
\hline L1_REER & 0.034 & 0.321 & 1.348 & 3.408 & 0.181 & 0.001 \\
\hline L2_D_CA & -0.179 & 0.271 & -1.456 & 0.589 & 0.149 & 0.558 \\
\hline L2_REER & -0.059 & 0.403 & -2.037 & 3.761 & 0.045 & 0.000 \\
\hline Threshold L1_D_CA & 0.165 & 1.199 & 0.742 & 1.446 & 0.460 & 0.152 \\
\hline Threshold L1_REER & -0.040 & -0.099 & -3.587 & -2.407 & 0.001 & 0.018 \\
\hline Threshold L2_D_CA & -0.297 & 0.418 & -1.340 & 0.505 & 0.184 & 0.615 \\
\hline Threshold L2_REER & 0.041 & 0.097 & 3.781 & 2.388 & 0.000 & 0.019 \\
\hline D_OPENC & -0.004 & 0.465 & -0.112 & 3.955 & 0.911 & 0.000 \\
\hline D_LINC & -0.087 & -0.553 & -0.981 & -1.678 & 0.330 & 0.097 \\
\hline D_FIN & 0.015 & -0.057 & 0.724 & -0.730 & 0.471 & 0.468 \\
\hline CONS & 0.048 & 0.566 & 0.789 & 2.468 & 0.433 & 0.016 \\
\hline
\end{tabular}

